





\title{
CHANGES IN ENZYME ACTIVITIES DURING THE PROGAME PHASE IN PETUNIA HYBRIDA
}

\author{
PROEFSCHRIFT \\ TER VERKRIJGING VAN DE GRAAD VAN \\ DOCTOR IN DE WISKUNDE EN NATUURWETENSCHAPPEN \\ AAN DE KATHOLIEKE UNIVERSITEIT TE NIJMEGEN \\ OP GEZAG VAN DE RECTOR MAGNIFICUS DR. A. J. H. VENDRIK, \\ HOOGLERAAR IN DE FACULTEITEN DER GENEESKUNDE \\ EN DER WISKUNDE EN NATUUR WETENSCHAPPEN, \\ VOLGENS BESLUIT VAN DE SENAAT \\ IN HET OPENBAAR TE VERDEDIGEN OP DINSDAG 27 JUNI 1967 \\ DES NAMIDDAGS TE 4 UUR \\ DOOR
}

HENRICUS PETRUS JOZEF ROCHUS ROGGEN

GEBOREN TE TEGELEN

H. VEENMAN \& ZONEN N.V. - WAGENINGEN 
Promotor: Prof. DR. H. F. Linskens 
Aan de nagedachtenis van mïn vader Aan mijn moeder 


\section{CONTENTS}

SAMENVATtING . . . . . . . . . . . . . . . . . . . . . . IX

SuMMARY .......................... 1

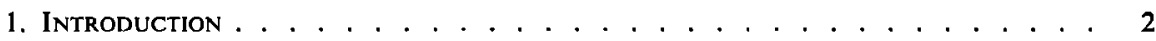

2. Material and methods . . . . . . . . . . . . . . . . . . . . . . . . . . 3

2.1. Material .................. . . 3

2.2. Analysis of the growth of pollen tubes . . . . . . . . . . . . . . . . 3

2.3. Preparing the extract . . . . . . . . . . . . . . . . . . . . . 3

2.4. Protein analysis . . . . . . . . . . . . . . . . . . . . . . . . . . . . 4

2.5. Enzyme tests . . . . . . . . . . . . . . . . . . . . . . . . . . . . . 4

2.6. Column chromatography of GDH . . . . . . . . . . . . . 7

2.7. Polyacrylamide gel electrophoresis and GDH coloring with Nitro-blue tetrazolium 7

2.8. Determination of radioactivity . . . . . . . . . . . . . . . . . . . . . . 8

2.9. Equipment and chemicals . . . . . . . . . . . . . . . . . . . . . . 8

3. Results . . . . . . . . . . . . . . . . . . . . . . . . . . . . . . . . . 9

3.1. Pollen tube growth after intraspecific compatible pollination W166K $\times \mathrm{T} 2 \mathrm{U}$. . 9

3.2. Comparison of enzyme activitics in pollinated styles, unpollinated styles and in pollen . . . . . . . . . . . . . . . . . . . . .

3.3. Comparison of enzyme activities of the pollen alone, and the pollinated and the unpollinated styles . . . . . . . . . . . . . . . . . . . . . 1

3.4. Inquiry into the nature of the alterations which take place within styles after pollination . . . . . . . . . . . . . . . . . .

3.5. Nature of the changes in the GDH which take place after pollination and during the growth of the $\mathrm{S}_{3}$ pollen through the $\mathrm{S}_{1} \mathrm{~S}_{2}$ style $\ldots \ldots . . . . . .16$

3.6. Studies concerning the activation of the GDH . . . . . . . . . . . . 21

4. Discussion ......... . . . . . . . . . . . . . . . . . . . . 24

4.1. Interaction of pollen tube and style at the metabolic level . . . . . . . . . . . . 24

4.2. Alterations in enzyme activities during the growth of the pollen tubes through the style . . . . . . . . . . . . . . . . . . . . . . . . . 25

4.3. The front wave advancing the growing pollen tubes . . . . . . . . . . . . . . . 27

4.4. Activation and de-novo synthesis of GDH after pollination . . . . . . . . . . 28

REFERENCES . . . . . . . . . . . . . . . . . . . . . . . . . . . . 29 


\section{SAMENVATTING}

$\mathrm{Na}$ de bestuiving van spermatophyta groeien de pollenbuizen door de stigma en de stijl, waarna de bevruchting kan plaats hebben in de ovula. Gedurende de groei van de vaak honderden pollenbuizen door de stijl treedt er interactie op tussen het stijlweefsel en de er doorheen groeiende pollenbuizen. Deze interactie komt tot uiting in allerlei metabolische veranderingen, die gepaard gaan met veranderingen in enzymactiviteiten. Enkele van deze veranderingen in enzymactiviteiten zijn onderzocht bij een compatibele bestuiving van Petunia hybrida.

De zure fosfatasen vertonen na de bestuiving een verlaging in activiteit; de andere onderzochte enzymen een verhoging. De verhoging in activiteit van het uridine difosfaatglucosedehydrogenase en het aspartaat carbamoyltransferase na de bestuiving is toe te schrijven aan de eigen activiteit van de pollenbuizen. $\mathrm{Er}$ is een kleine verhoging van het alanine aminotransferase, het aspartaat aminotransferase (AsAT) en het glutamaat dehydrogenase (desaminering) (GDH desamin.), die niet toegeschreven kan worden aan de activiteits verhoging veroorzaakt door de pollenbuizen alleen. Grote verhogingen in activiteit van de enzymen van het koolhydraat metabolisme hebben plaats nl. van het ketosel-fosfaat aldolase (KPA) en het citraat synthase. Een belangrijk enzym voor de aminozuur synthese is het glutamaat dehydrogenase (aminering) (GDH amin.), dat ook een grote verhoging in activiteit vertoont na bestuiving.

Uit interactie experimenten is gebleken dat er reeds een uitwisseling van stoffen in dat gedeelte van de stijl waar nog geen pollenbuizen zijn gegroeid plaats heeft. Het GDH amin. en het AsAT vertonen daarin een hogere activiteit die vooruitloopt op de pollenbuisgroei. Er ontstaat dus een golf van enzymactiveringen in de stijl voorafgaande aan de pollenbuisgroei. De verhoging van de KPA activiteit is echter beperkt tot de plaats waar de pollenbuizen groeien.

De opname in het ruwe extract en de inbouw in de protein fractie is voor en na de bestuiving bepaald met verschillende ${ }^{14} \mathrm{C}$-aminozuren. Zowel voor als na de bestuiving is er een opname van de toegediende aminozuren in het ruwe stijl extract en een inbouw in de eiwitfractie. De moeilijk te metaboliseren aminozuren ${ }^{14} \mathrm{C}$-leucine en ${ }^{14} \mathrm{C}$-threonine worden na de bestuiving $10 \%$ meer ingebouwd in de eiwitten, maar de opname er voor en er na in het ruwe extract is ongeveer hetzelfde. Er wordt minder ${ }^{14} \mathrm{C}$-proline en ${ }^{14} \mathrm{C}$-proteine hydrolysaat opgenomen en ingebouwd in bestoven stijlen, doordat een gedeelte van deze gemakkelijk te metaboliseren aminozuren afgebroken worden of voor de pollenbuiswand synthese gebruikt worden.

Het is gebleken dat het GDH van het pollen verschilt van dat van de plant, zodat men kan spreken van isoenzymen. Het GDH van het pollen wordt gedurende de doorgroei van de pollenbuizen de-novo gesynthetiseerd, doch bovendien wordt het GDH van de stijl onder invloed van de pollenbuisgroei geactiveerd door structuur veranderingen van het GDH molecuul. Door het bij elkaar brengen van het pollen- en stijlextract wordt het GDH desamin. van de stijl 
door een niet dialyseerbare activator uit het pollen geactiveerd. Het GDH van zowel het pollen als van de stijl is $\mathrm{NAD}^{+}$specifiek en heeft geen alanine dehydrogenase activiteit.

De resultaten van dit onderzoek tonen aan, dat voorafgaande aan de eigenlijke versmelting van de sexuele cellen (syngamie) tijdens de progame fase reeds een intensieve metabolische interactie tussen de twee geslachtspartners plaats heeft. Reeds voordat de in de mannelijke kernen van de pollenbuis gelocaliseerde informaties in contact komen met de eicel treffen tijdens de passage van mannelijke pollenbuizen door het vrouwelijk weefsel van de stijl enzymen en substraten van de twee partners elkaar. Voor een compatibele bevruchting is vereist, dat deze systemen op elkaar afgestemd zijn en op metabolisch niveau de voorwaarden scheppen, dat de pollenbuizen in staat zijn hun doel te bereiken.

Daarbij vindt een wederzijdse remming, activering of de-novo synthese plaats van bepaalde enzymen.

De coördinatie van de twee in interactie verkerende systemen in ruimte en tijd is noodzakelijk voor een succesvolle compatibele bevruchting. 


\section{SUMMARY}

Pollen tubes grow through the stigma and the style after pollınatıon of spermatophyta, whereupon fertilization can take place in the ovules During the growth of hundreds of pollen tubes through the style, an interaction occurs between the style tissue and the pollen tubes This interaction finds expression in various kinds of metabolic changes which are coupled with alterations in enzyme activities Some of these changes in enzyme activities are examined following compatıble pollınation of Petuma hvbrida

The acid phosphatases exhibit a decrease in activity after pollinatıon The other investigated enzymes show an increase Following pollination the increase in activity of uridine diphosphate glucose dehydrogenase and the aspartate carbamoyltransferase can be ascribed to the characteristic activities of the pollen tubes There is a small increase in the alanine aminotransferase, the aspartate amınotransferase (AsAT) and the glutamate dehydrogenase (deamınation) (GDH deamin) that cannot be ascribed to the increase in activity caused by the pollen tubes alone Large increases in activity of the enzymes of the carbohydrate metabolism take place, vIz of the ketose-l-phosphate aldolase (KPA) and the citrate synthase An Important enzyme for the amino acid synthesıs, the glutamate dehydrogenase (amınation) (GDH amın ) shows also a greal increase in actıvity after pollination

It has become clear from interaction experiments that an exchange of substances occurs betwcen the pollen tubes and the untouched section of the style where pollen tubes have not yet grown The GDH amın and the AsAT show a greater activity in the untouched tissue which anticipates the growth of the pollen tubes Thus, a wave of enzyme actvities arise in the style preceding the growth of the pollen tubes The increase in the KPA activity, however, is localized to the site of the pollen tube growth

The uptake into the crude extract and the incorporation into the protein fraction were determıned beforc and after pollınation with different ${ }^{~} \mathrm{C}$-amıno acids Both beforc and after pollınation, there is an uptake of different ${ }^{14} \mathrm{C}$-labelled amıno acids into the crude style extract and an incorporation into the protein fractions The incorporation into the proteins of the difficult to metabolıze amıno acıds, namely "C-leucine and ${ }^{14} \mathrm{C}$-thrconine, is $10 \%$ greater after pollination, but the uptake in the crude extract is about the same before and after There is less ${ }^{14} \mathrm{C}$-proline and ${ }^{14} \mathrm{C}$-protein hydrolysate taken up and incorporated in the pollinated styles because a pertion of these easy to metabolize amino acids is decomposed or is used for pollen tube uall synthesis

It is evident that the GDH of the pollen differs from that of the plant, so that one may speak of isoenzymes The GDH of the pollen is synthesized de-novo during the growth of the tubes Furthermore, the GDH of the style is activated under the influence of the pollen tube growth which induces conformational changes in the GDH molecule By joining the pollenand style extract, the GDH deamın of the style is activated by an undialyzable activator from the pollen The GDH from both pollen and style are NAD ${ }^{+}$specific and have no alanıne dehydrogenase actıvity

* Present adress I V T Wagenıngen

Acta Bot Neerl 16(I), July 1967 


\section{INTRODUCTION}

In order to accomplish fertilization in spermatophyta, it is necessary that the information stored in the generative nucleus of the pollen reaches the ovule. Pollination is first needed, followed by the progame phase (Polyakov 1964), during which the pollen germinate and form tubes which penetrate the stigma and grow through the conducting tissue of the style to the ovary. At this stage the progame phase is ended. Fertilization ends with the syngamy of the sexual nuclei in the embryo sac.

Germination is easy to imitate in vitro by placing the pollen in a suitable medium. In vitro germination experiments have been extensively done and have been reviewed (JOHRI \& VASIL 1961; LINSKENS 1964a). It has become clear that increases in enzyme activities take place during the pollen germination in vitro. This is not surprising since the mere administration of water forces the dry pollen out of their condition of rest and high enzyme activities are needed for the formation of pollen tubes. This pollen germination is coupled with changes in the sub-microscopical structure (SASSEN 1964; ROSEN c.s. 1964; LARSON 1965).

Also, in vivo enzymes of the pollen grain are activated within a few minutes after contact with the stigma surface (STANLEY \& LINSKENS 1964a).

The growth of the pollen tubes through the conducting tissue of the style is very important for it removes the spatial disjunction of the gametes.

Under the influence of the pollen tubes which forge their way through the style, several kinds of alterations take place: the respiration is stimulated (Hsiang 1951; LinSKENS 1955); the content of the growth hormones increases rapidly (LUND 1956); the quantities of starch and free sugars alter (LINSKENS 1955; TUPÝ 1961a; PYL'NEV 1962) just as the concentration of free amino acids (LinsKens 1955; BELlaRTZ 1956; TUPÝ 1961b) and the amount and the composition of proteins do (LINSKENS 1955; LiNSKENS \& TUPÝ 1966). These alterations must be accompanied by changes in enzyme activities. For the manufacture of tube material and for the growth through the style, pollen tubes have a comprehensive set of enzymes at their disposal viz.: catalase, acid phosphatases, amylase, invertase, peroxidases, pectinase, tyrosinase and cytochrome oxidase (Paton 1921; Vinson 1927; Haeckel 1951; Iwanami 1956; PoddubNAYA-ARNOLDI c.s. 1961). Enzymes are involved in vivo as was demonstrated by SCHOCH-BOdmer \& Huber $(1945,1947)$. Stylar cell wall material can be solved by exoenzymes excreted at the pollen tube tips. It has become clear from histochemical studies that there are increases in the activities of peroxidase, dehydrogenases (PYL'NEV \& PYL'NeVA 1963) acid phosphatases, amylase and cytochrome oxidase (SCHLösSER 1961). During the growth of the pollen tubes through the style, an alteration of the enzymatic mechanism takes place in which there is a shift of the glucose metabolism from the Embden-Mayerhoff pathway to the anaerobic respiration via the hexose-mono-phosphate-shunt (STANLEY 1958).

In vitro pollen germination experiments concerning enzyme activities give only to a certain extent information about processes which will occur in vivo. However, little is known about the alterations of enzyme activities after polli- 


\section{ENZYME ACTIVITIES DURING PROGAME PHASE IN PETUNIA}

nation and even less is known concerning the nature of these changes. The joining of the pollen tubes and stylar tissue is characterized by the meeting of two groups of enzymes and substrates, which react with each other. The alterations accompanying it are not yet known.

The intention of this paper is to report on enzymological investigations into what is occuring during the growth of compatible pollen tubes through the style of Petunia hybrida.

\section{Abbreviations}

AlAT: Alanine aminotransferase; AsAT: Aspartate aminotransferase; CoA: Coenzyme A; DEAE-cellulose: Diethylaminoethyl-cellulose; EDTA: Ethylene diaminetetraacetate-Na salt; GDH: Glutamate dehydrogenase; KPA: Ketose1-phosphate aldolase; $\mathrm{NAD}^{+}$: Nicotinamide adenine dinucleotide; NADH: reduced Nicotinamide adenine dinucleotide; PMS: Phenazinemethosulphate; TRA: Triethanolamino-hydrochloride; TRIS: Tris (hydroxymethyl) aminomethane; UDP: Uridine diphosphate; UDPGDH: Uridine diphosphate glucose dehydrogenase.

\section{MATERIAL AND METHODS}

\subsection{Material}

The clones W166K and T2U of Petunia hybrida were used as the sources of material. These clones were originally developed by STRAUB (1946) and are self-incompatible possessing the self-incompatibility alleles $S_{1} S_{2}$ and $S_{3} S_{3}$ respectively. However, only the compatible intraspecific combination Wl66K $\times$ T2U was studied. Plants were cultivated in a greenhouse in normal daylight supplemented with Mercury lamps (8:00-00:00 h., Philips HW 500, intensity about 10,000 lux). The flowers were gathered in the bud stage just before the anthesis. After cleaving the corolla with tweezers, the anthers were removed. Following three or four hours of acclimatizing in a beaker filled with tap water in an oven at $25^{\circ} \mathrm{C}$, one group of these flowers was abundantly pollinated with fresh pollen and the other was left unpollinated. At selected times after pollination, styles were collected and used for the analyses.

\subsection{Analysis of the growth of pollen tubes}

After treatment of the squashed styles with Wasserblau, the pollen tubes are visible in the fluorescence microscope (LINSKENS \& ESSER 1957). Using the millimeter scale the distance which the six fastest-growing pollen tubes had covered through the styles was measured.

\subsection{Preparing the extract}

Prior to extraction, the stigmata were removed from both pollinated and unpollinated styles with a sharp razor blade, so that the germinated and ungerminated pollen, still present on the stigma, were not included in the extract. In this way, only the styles were extracted. Consequently, the analyses of the 
processes during the first threc to four hours are lost because the pollen have not yet penetrated into the styles. Analyses carried out within four hours after pollınation do not show any significant alteratıon in activity with regard to the unpollinated control. It is not very likely that an explosion of enzyme activities is takıng place in the whole style durıng the first three hours because in all enzyme analyses the activity rises from control values at three hours until the maxımum is reached after 10 or 12 hours. The styles were homogenized in a cooled mortar and pestle together with a small amount of pure quartz sand and the same buffer with which the enzyme tests (2.5) were carried out. The quantity of extract buffer was chosen in such a manner that 1 to $2 \mathrm{mg}$ protein per $\mathrm{ml}$ was present. Following homogenızation at $4^{\circ} \mathrm{C}$ durıng 20 minutes, the extracts were centrifuged for $20 \mathrm{~min}$ at $8000 \mathrm{~g}$ at $4^{\circ} \mathrm{C}$ and the clear supernatant was used for varıous cnzyme tests.

\subsection{Protein analysis}

The amount of protein was analyzed by the biuret reaction (GORNALL c.s. 1949 as modified by HEI $\backslash E N$ 1963).

\subsection{Enzyme tests}

2.5.1 Acıd phosphatase (EC 3.1.3.2 ${ }^{1}$ ) and alkalıne phosphatase (EC 3.1.3.1).

The phosphatases catalıze the hydrolitical splitting of monophosphoric esters. P-nitrophenylphosphate is used as substrate for the acid phosphatases as well as for the alkaline phosphatases. After the phosphate is removed, the yellow color of p-nitrophenol in alkalıne milieu can be measured in a colorimeter. The amount of per time unit released p-nitrophenol is a standard for the phosphatase activity. The activity is expressed as the extınction at $546 \mathrm{~nm}$ caused by $1 \mathrm{mg}$ protein in $1.20 \mathrm{ml}$ reaction mixture during $30 \mathrm{~min}$ at $37^{\circ} \mathrm{C}$ measured against a blank with water.

\subsubsection{Ketose-l-phosphate aldolase (KPA) (EC 4.1.2.7)}

KPA catalizes the reaction: fructose-1,6-diphosphate $\rightleftharpoons$ D-glyceraldehyde-3phosphate $\mid$ dihydroxyacetone-phosphate. In the absence of triose phosphate isomerase (EC 5.3.1.1) the two triose phosphates are present in equal quantities at equilibrium. However, when this enzyme is added, conversion of D-glyceraldehyde-3-phosphate to dihydroxyacetone-phosphate is catalized. At equilibrium $96 \%$ of the triose phosphate is present as dihydroxyacetone-phosphate. The latter is reduced by NADH in the presence of $\alpha$-glycerophosphate dehydrogenase (EC 1.1.1.8) according to the reaction: 2 dihydroxyacetone phosphate $2 \mathrm{NADH}-2 \mathrm{H}^{+} \rightarrow 2 x$-glycerophosphate $+2 \mathrm{NAD}$. When these reactions are combined together, the sum reaction is: fructose-1,6-diphosphate +2 $\mathrm{NADH}+2 \mathrm{H}^{+}>2 x$-glycerophosphate $+2 \mathrm{NAD}^{+}$.

The consumption of NADH is proportional to the cleaved quantity of fructose-1,6-diphosphate, if aldoldse is the limitıng factor. The reaction mix-

1) See Enzyme Nomenclature Unıon of Biochemıstry Elsevier Publ Comp AmsterdamLondon-New York 1965 
ture contained: $2.75 \mathrm{ml} 0.056 \mathrm{M}$ Collidine buffer $\mathrm{pH} 7.4 ; 10^{-4} \mathrm{M}$ mono iodoacetate; $2 \times 10^{3} \mathrm{M}$ fructose-1,6-diphosphate; $0.05 \mathrm{ml} 0.015 \mathrm{M} \mathrm{NADH} ; 0.01 \mathrm{ml}$ glycerophosphate dehydrogenase/triose phosphate isomerase $(2 \mathrm{mg}$ enzyme protein per $\mathrm{ml}$ (see 2.9), $\mathrm{x} \mathrm{ml}$ enzyme extract and $\mathrm{y} \mathrm{ml}$ water to a total of $3 \mathrm{ml}$.

The activities are expressed as the change in extinction $(\Delta E)$ at $340 \mathrm{~nm}$ caused by $1 \mathrm{mg}$ protein in $3 \mathrm{ml}$ reaction mixture after 10 minutes at $37^{\circ} \mathrm{C}$.

\subsubsection{Alanine aminotransferase (AlAT) (EC 2.6.2.1) and Aspartate amino- transferase (AsAT) (EC 2.6.1.1)}

AlAT catalizes the reversible reaction alanine +2 -oxoglutarate $\rightleftharpoons$ glutamate + pyruvate. By addition of lactate dehydrogenase (EC 1.1.1.27), the developed pyruvate is coupled with the reaction: pyruvate $+\mathrm{NADH}-\mathrm{H}^{\vdash} \rightleftharpoons$ lactate + NAD'. The NADH consumption is proportional to the amount of formed pyruvate and indicates the activity of the AlAT. The reaction mixture contained: $2.70 \mathrm{ml} 0.1 \mathrm{M}$ phosphate buffer $\mathrm{pH} 7.4+0.11 \mathrm{M}$ alanine; $0.05 \mathrm{ml} 1.2 \times 10^{-2}$ $\mathrm{M} \mathrm{NADH} ; 0.05 \mathrm{ml} 0.050 \mathrm{mg} / \mathrm{ml}$ lactate dehydrogenase (see 2.9 ); $\mathrm{x} \mathrm{ml} \mathrm{enzyme}$ extract; and y $\mathrm{ml}$ water to a total of $2.90 \mathrm{ml}$.

After standing $10 \mathrm{~min}$ at $25^{\circ} \mathrm{C} 0.10 \mathrm{ml} 0.2 \mathrm{M}$ sodiumglutarate was added. The extinction decrease $\Delta E$ at $340 \mathrm{~nm}$ as a result of the transformation of NADH into $\mathrm{NAD}^{-1}$ caused by $1 \mathrm{mg}$ protein in $10 \mathrm{~min}$ at $25^{\circ} \mathrm{C}$ in the above mentioned reaction mixture was used as a measure of activity.

AsAT catalizes the revesible reaction: glutamate $\perp$ oxaloacetate $\rightleftharpoons$ aspartate +2 -oxoglutarate. The activity of the transaminase is measured by reacting the oxaloacetate, which was caused by the reaction proceeding from right to left, with 2,4-dinitrophenylhydrazine. The color of the hydrazone that is formed in alkaline milieu is proportional to the amount of formed oxaloacetate and thus represents the extent of the transaminase activity. The analysis is carried out as follows: $1.00 \mathrm{ml} 0.1 \mathrm{M}$ phosphate buffer $\mathrm{pH} 7.4$ containing $0.1 \mathrm{M}$ L-aspertate and $2 \times 10^{-3} \mathrm{M}$ 2-oxoglutarate; $\mathrm{x} \mathrm{ml} \mathrm{enzyme} \mathrm{extract} \mathrm{and} \mathrm{y} \mathrm{ml}$ water to a total of $1.2 \mathrm{ml}$. After incubating this $60 \mathrm{~min}$ at $37^{\circ} \mathrm{C} 1 \mathrm{ml} 0.001 \mathrm{M} \mathrm{2,4-dinitrophenyl-}$ hydrazine is added and the mixture is left at room temperature for $20 \mathrm{~min}$. Then $10 \mathrm{ml} 0.4 \mathrm{M} \mathrm{NaOH}$ is added and after $5 \mathrm{~min}$ the extinctions are measured against a blank which contained water instead of the enzyme extract. The extinction at $546 \mathrm{~nm}$ caused by $1 \mathrm{mg}$ enzyme extract in the above mentioned reaction mixture is used as the measure of the AsAT activity.

\subsubsection{Glutamate dehydrogenase (EC 1.4.1.3)}

The activity of this enzyme is analyzed in two directions by means of an absorption change at $340 \mathrm{~nm}$ when the proportion of the NADH and NAD ${ }^{+}$ alters.

\subsubsection{Direction of the amination (GDH amin.)}

This enzyme catalizes the reaction: 2-oxoglutarate $+\mathrm{NH}_{3}+\mathrm{NADH}+\mathrm{H}^{+} \rightarrow$ L-glutamate $+\mathrm{H}_{2} \mathrm{O}+\mathrm{NAD}^{+}$. The following reaction mixture is prepared: $2.00 \mathrm{ml} 0.05 \mathrm{M}$ triethanolamine buffer $\mathrm{pH} 7.8+0.004 \mathrm{M}$ EDTA; $0.10 \mathrm{ml} 3.2 \mathrm{M}$ ammonium acetate; $0.05 \mathrm{ml} 0.001 \mathrm{M} \mathrm{NADH} ; \mathrm{x} \mathrm{ml}$ enzyme extract; and y $\mathrm{ml}$ 
water to a total of $2.50 \mathrm{ml}$. Extraneous NADH oxidation, if any, is measured and the reaction is then started by adding $0.05 \mathrm{ml} 0.4 \mathrm{M}$ 2-oxoglutarate neutralized with $\mathrm{NaOH}$. The decrease in the extinction $\Delta \mathrm{E}$ at $340 \mathrm{~nm}$ as a consequence of the oxidation of $\mathrm{NADH}$ to $\mathrm{NAD}^{\vdash}$ during $10 \mathrm{~min}$ at $25^{\circ} \mathrm{C}$ caused by $1 \mathrm{mg}$ protein in the above mentioned reaction mixture is used as a measure of activity.

\subsubsection{Direction of the deamination (GDH deamin.)}

This enzyme catalizes the reaction: L-glutamate $+\mathrm{H}_{2} \mathrm{O}+\mathrm{NAD}^{+} \rightarrow 2$-oxoglutarate $+\mathrm{NH}_{3}+\mathrm{NADH}+\mathbf{H}^{+}$. The following reaction mixture is employed: $2.00 \mathrm{ml}$ buffer as under $2.5 .4 .1 ; 0.05 \mathrm{ml} 0.001 \mathrm{M} \mathrm{NAD}^{+} ; 0.025 \mathrm{ml}$ $0.4 \mathrm{M}$ L-glutamate neutralized with $\mathrm{NaOH}$; $\mathrm{x}$ ml extract; and y ml water to a total of $2.50 \mathrm{ml}$. The increase in the extinction $(\Delta \mathrm{E})$ at $340 \mathrm{~nm}$ as a consequence of the reduction of NAD to NADH during $10 \mathrm{~min}$ at $25^{\circ} \mathrm{C}$ caused by $1 \mathrm{mg}$ protein in the above mentioned reaction mixture is used as a measure of activity.

2.5.5 Uridine diphosphate glucose dehydrogenase (UDPGDH) (EC 1.1.1.22) This enzyme catalizes the reaction: UDP-glucose $+2 \mathrm{NAD}^{+}+\mathrm{H}_{2} \mathrm{O} \rightleftharpoons$ UDPglucuronate $\perp 2 \mathrm{NADH}_{2}-2 \mathrm{H}^{+}$. The following reaction mixture is employed: $2.00 \mathrm{ml} \mathrm{0.2} \mathrm{M}$ tris- $\mathrm{HCl}$ buffer $\mathrm{pH} 8.7 ; 0.25 \mathrm{ml} 0.001 \mathrm{M}$ uridine diphosphate glucose; $0.05 \mathrm{ml} 0.025 \mathrm{M} \mathrm{NAD}^{-}$; $\mathrm{x} \mathrm{ml} \mathrm{extract;} \mathrm{and} \mathrm{y} \mathrm{ml} \mathrm{water} \mathrm{to} \mathrm{a} \mathrm{total} \mathrm{of}$ $2.50 \mathrm{ml}$. The increase in the extinction $(\Delta \mathrm{E})$ at $340 \mathrm{~nm}$ as a consequence of the transformation of $\mathrm{NAD}^{-}$into NADH during $10 \mathrm{~min}$ at $25^{\circ} \mathrm{C}$ caused by $1 \mathrm{mg}$ protein in the above mentioned reaction mixture is used as a measure of activity.

\subsubsection{Aspartate carbamoyltransferase (EC 2.1.3.2)}

This enzyme catalizes the following reaction: carbamoylphosphate + Laspartate $\rightleftharpoons$ orthophosphate $+\mathrm{N}$-carbamoyl-L-aspartate. The aspartate carbamoyltransferase test was carried out in the following incubation medium (Gerhard \& PARDeE 1962): $15 \mathrm{mM}$ L-aspartate; $8 \mathrm{mM}$ dilithium carbamoylphosphate; $50 \mathrm{mM}$ tris- $\mathrm{HCl}$ buffer $\mathrm{pH} 7.0 ; 0.2 \mathrm{ml}$ enzyme (extracted with $0.005 \mathrm{M}$ phosphate buffer $\mathrm{pH} 7.0$ ); total volume $1 \mathrm{ml}$.

The $\mathrm{N}$-carbamoyl-L-aspartate which is formed during the $30 \mathrm{~min}$ incubation at $28^{\circ} \mathrm{C}$, can be analyzed according to the procedure of KORITZ \& COHEN (1954). To $1 \mathrm{ml}$ incubation medium was added: $2.00 \mathrm{ml} 50 \% \mathrm{H}_{2} \mathrm{SO}_{4} ; 0.035 \mathrm{ml} 1 \%$ sodium diphenylamine; and $0.08 \mathrm{ml}$ diacetyl monoxime. After shaking the mixture is boiled in a water bath for $10 \mathrm{~min}$ and is cooled in streaming tap water. After adding $0.08 \mathrm{ml}$ of $1 \%$ potassium persulphate and shaking quickly, the samples are placed in boiling water for another minute. They are then cooled down again in streaming water in the dark to room temperature and after $10 \mathrm{~min}$, the extinction is measured at $546 \mathrm{~nm}$ against a blank treated in the same way except that the enzyme is replaced by water. The extinction at $546 \mathrm{~nm}$ in $1 \mathrm{~cm}$ glass cuvettes caused by the formed and colored $\mathrm{N}$-carbamoyl-L-aspartate is used as the measure of activity. 


\subsubsection{Citrate synthase (EC 4.1.3.7) (condensing enzyme)}

This enzyme catalizes the reaction: acetyl-CoA $+\mathrm{H}_{2} \mathrm{O} \perp$ oxaloacetate $\rightleftharpoons$ citrate $+\mathrm{CoA}$. For the analysis of this enzyme, the above reaction is coupled through addition of malate dehydrogenase to the reaction L-malate ; $\mathrm{NAD}^{+}$ $\rightleftharpoons$ oxaloacetate $+\mathrm{NADH}+\mathrm{H}^{+}$, so that the complete reaction is: acetyl-CoA + L-malate $+\mathrm{NAD}+-\mathrm{H}_{2} \mathrm{O} \rightleftharpoons$ citrate $-\mathrm{CoA}-\mathrm{NADH}+\mathrm{H}^{+}$. The reduction of $\mathrm{NAD}^{+}$to $\mathrm{NADH}$ is used as a measure of the activity of the citrate synthase. The following reaction mixture is prepared (OсHOA 1955) in $1 / 2 \mathrm{~cm}$ quartz cuvettes: $0.75 \mathrm{ml} 0.1 \mathrm{M}$ tris- $\mathrm{HCl} \mathrm{pH} 8.0 ; 0.20 \mathrm{ml} 0.05 \mathrm{M}$ potassium-Lmalate; $0.10 \mathrm{ml} 0.008 \mathrm{M} \mathrm{NAD}^{+}$; malate dehydrogenase $3 \gamma=150-200$ units (Boehringer); $0.03 \mathrm{ml}$ acetyl-CoA; $\mathrm{x} \mathrm{ml} \mathrm{enzyme;} \mathrm{and} \mathrm{y} \mathrm{ml}$ water to a total of $1.5 \mathrm{ml}$. The acetyl-CoA is prepared from CoA using the method of Simon and Shemin (Simon \& Sifmin 1953). The extinction increase ( $\Delta E$ ) at $340 \mathrm{~nm}$ caused by the transformation of $\mathrm{NAD}^{+}$into $\mathrm{NADH}$ during $10 \mathrm{~min}$ at $25^{\circ} \mathrm{C}$ by $1 \mathrm{mg}$ protein is taken as the measure of activity.

\subsection{Column chromatography of GDH}

\subsubsection{Column chromatography of GDH on DEAE-cellulose}

The column employed was $1 \times 16 \mathrm{~cm}$ and was filled with DEAE-cellulose. After washing with $50 \mathrm{ml}$ triethanolamine buffer $\mathrm{pH} 8.0+0.02 \mathrm{M}$ EDTA, the style extract was applied and was eluated with a linear $(0.02-0.40 \mathrm{M}) \mathrm{NaCl}$ gradient in $0.05 \mathrm{M}$ TRA buffer $\mathrm{pH} 7.8+0.003 \mathrm{M}$ EDTA with a flow rate of $6 \mathrm{ml} / \mathrm{h}$. The fractions of $1 \mathrm{ml}$ were collected with a fraction collector and tested for the GDH amin. acitivity. To extract the GDH, 70 styles were homogenized with $1.5 \mathrm{ml} 0.05 \mathrm{M}$ TRA buffer $\mathrm{pH} 7.8+0.003 \mathrm{M}$ EDTA. After centrifuging for $20 \mathrm{~min}$ at $8000 \times \mathrm{g}, 1 \mathrm{ml}$ of the clear supernatant was placed on the column.

\subsubsection{Column chromatography of GDH on Sephadex G 200}

A column of $2.5 \times 40 \mathrm{~cm}$ was prepared with Sephadex G 200, which was swelled for 48 hours in $0.05 \mathrm{M}$ TRA buffer $\mathrm{pH} 7.8+0.002 \mathrm{M}$ EDTA. An extract was made of 1000 Wl66K styles $(t 5 \mathrm{gr}$ fresh weight) with $10 \mathrm{ml}$ buffer in the same way as described in 2.6.1. To lessen the volume, the extract was dialyzed in a collodion tube at $4^{\circ} \mathrm{C}$ against water under a relative air pressure of $0.7 \mathrm{~atm}$ until the volume was reduced to $1.5 \mathrm{ml}$. The eluating buffer was the same as the extraction buffer and $2 \mathrm{ml}$ fractions were collected.

\subsection{Polyacrylamide gel electrophoresis and GDH coloring with} Nitro-blue tetrazolium

Separation of the proteins was carried out with disc electrophoresis according to ORNSTEIN (1964) and DavIS (1964). Coloring of the GDH was accomplished with the reaction sequence: glutamate $+\mathrm{H}_{2} \mathrm{O}+\mathrm{NAD}^{+} \rightleftharpoons 2$-oxoglutarate + $\mathrm{NH}_{3}-\mathrm{NADH}+\mathrm{H}^{\prime} ; \mathrm{NADH}-$ phenazinemethosulphate $->\mathrm{NAD}^{-}+$ reduced PMS; reduced PMS + nitro-bluetetrazolium (colorless) $\rightarrow$ PMS + reduced nitro-bluetetrazolium (purple). 
This reaction is carried out as described by ZoNDAG (1964) with glutamate as substrate. The gels are incubated for 1.5 hour at $30^{\circ} \mathrm{C}$.

\subsection{Determination of radioactivity}

2.8.1 Determination of radioactivity in GDH labelled with ${ }^{14} \mathrm{C}$-leucine and separated on polyacrylamide gels

After staining the GDH (see 2.7), the colored zones were sliced out of the gels and hydrolized for 12 hours in concentrated $\mathrm{HCl}$ at $120^{\circ} \mathrm{C}$ in sealed glass tubes. A sample of $0.5 \mathrm{ml}$ of this hydrolysate was dissolved in $20 \mathrm{ml}$ scintillation fluid (toluene-alcohol 1:1 - 0.4\% PPO and 0.005\% POPOP, both from Pilot Chemicals Inc.). The counting was done in a Tricarb liquid scintillation counter (Packard) with estimated efficiency of $45 \%$.

2.8.2 Determination of radioactivity in crude extracts and proteins labelled with different ${ }^{14} \mathrm{C}$-amino acids

Dried samples were counted with a G.M.-type tube (Philips 18505).

\subsection{Equipment and chemicals}

The colorimetric tests were analyzed in the Eppendorf colorimeter in $1 \mathrm{~cm}$ glass cuvettes.

The analysis of the oxidoreductases was carried out with the Zeiss PMQ II spectrophotometer or the Bausch and Lomb Spectronic 505 with an attached Hitachi QPD 33 recorder. The holder for the $1 \mathrm{~cm}$ quartz cuvettes was equipped with an arrangement to hold the temperature constant. The fraction collector with associated apparatus came from L.K.B. The acid and alkaline phosphatases, the KPA, the AsAT and AIAT were analyzed with the test combinations TC-P; TC-Q; TC-D; TC-R; and TC-S respectively of Boehringer, Mannheim, W. Germany. The radioactive compounds were obtained from the Radiochemical Centre, Amersham, England. All the other chemicals were ordered in the highest degree of purity from BDH, Boehringer, Merck, NBC, Pharmacia and Serva.

\section{Acknowledgements}

The plant material was kindly supplied by Prof. Dr. H. F. LINSKens and was well cared for by Mr. W. FloKSTRA. I extend my thanks to DR. W. HeINEN for his stimulating discussion; to DR. L. A. SMETS for preparing and counting the liquid scintillation samples; to Mr. C. A. Godfrey B. A. for checking the English translation and to Mrs. M. J. F. E. SMULders-Aghina for translating and typing the manuscript. Mr. B. KnUIMAN carried out the separation of proteins on disc electrophoresis. Many thanks to DR. O. BANGA, director of the Institute of Horticultural Plant Breeding (Wageningen) for kindly allowing me to finish the manuscript. 


\section{RESULTS}

3.1 Pollen tube growth after intraspecific compatible pollination W166K $\times$ T $2 \mathrm{U}$

In the combination $\mathrm{W} 166 \mathrm{~K} \times \mathrm{T} 2 \mathrm{U}\left(\mathrm{S}_{1} \mathrm{~S}_{2} \times \mathrm{S}_{3}\right) \pm 400$ pollen tubes per style grow through the conducting tissue at the rate of approximately $1 \mathrm{~mm} / \mathrm{h}(f \mathrm{~g} . l)$. The growth of the pollen tubes in the cut buds is the same as when the buds are left on the plant (LINSKENS \& TUPY 1966). Alterations occur in the styles due to this active growth of the pollen tubes. First various divergent enzymes of the cell metabolism are screened.

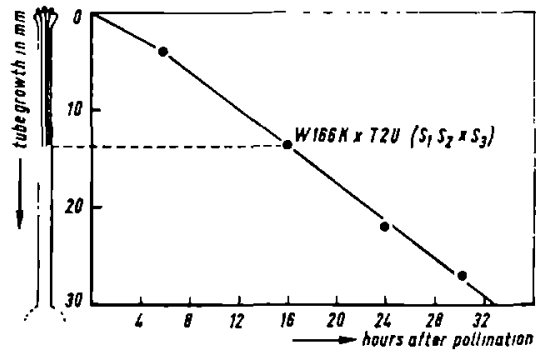

Fig. 1. Growth rate of T2U $\left(\mathrm{S}_{3}\right)$ pollen tubes in the style of Petunia clone W166K $\left(S_{1}\right.$ $\mathbf{S}_{\mathbf{2}}$ ).

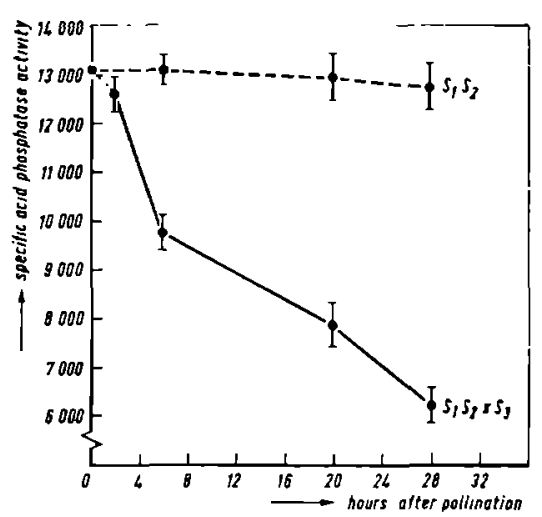

Fig. 2. Alteration in the activity of the specific acid phosphatase in cross-pollinated and unpollinated styles at various times after pollination.

3.2 Comparison of enzyme activities in pollinated styles, unpollinated styles and in pollen

\subsubsection{Changes in acid and alkaline phosphatase activities}

The alkaline phosphatases were not demonstrable either in the pollinated or in the unpollinated styles and $S_{3}$ pollen. On the other hand, the acid phosphatases are present in very high activity, but it is observed in fig. 2 that this activity decreases about $50 \%$ after pollination. This is in contrast to all other tested enzymes in which increases of activity developed after pollination.

\subsubsection{Alteration in the activity of KPA}

It appears from fig. 3 that a specific increase in activity of KPA of $50 \%$ occurs, which falls back to the control value of the unpollinated styles as the pollen tubes complete their growth through the style. Numerous experiments were performed in order to determine whether the increase of activity after pollination on the plant is as great as after cutting of the buds as mentioned in 2.1. It was evident, that as far as the KPA activity was concerned, it made no difference whether the flowers were pollinated on the plant in the greenhouse or if they were cut off and placed in water. 


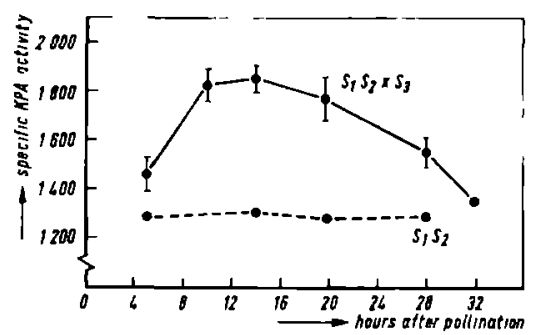

Fig. 3. Alteration in the KPA activity at various times after cross-pollination.

\subsubsection{AsAT and AlAT activities}

The increases in activity of AsAT and AIAT after pollination are small, that is, approximately 10 to $15 \%$ (see fig. 4 and 5). The specific activity of AsAT is $15 \times$ greater than that of AlAT.

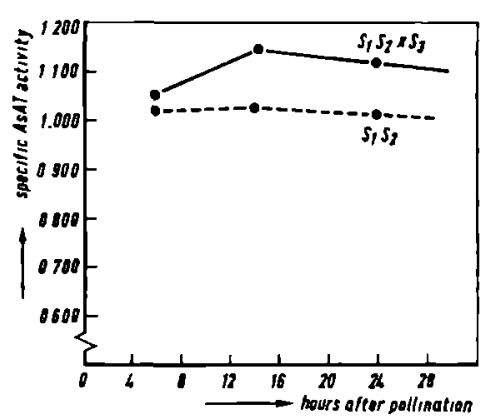

Fig. 4. The specific activity of AsAT at various times after cross-pollination.

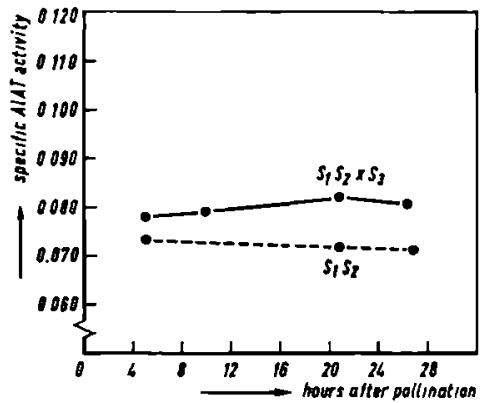

Fig. 5. The specific activity of AIAT at various times after cross-pollination.

\subsubsection{Alteration in GDH amin. activity}

It is apparent that after pollination the activity of GDH amin. has increased $50 \%$ (fig. 6).

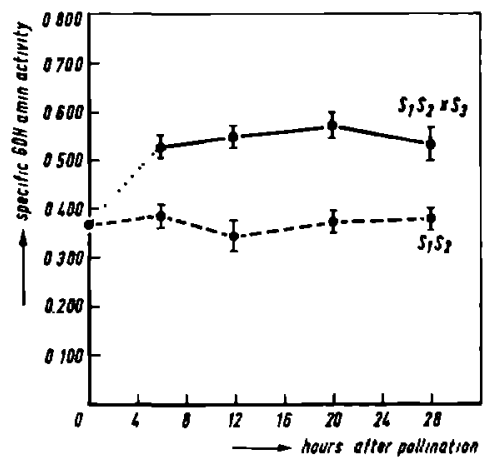

Fig. 6. Alteration in the specific activity of $\mathrm{GDH}$ amin. after cross-pollination.

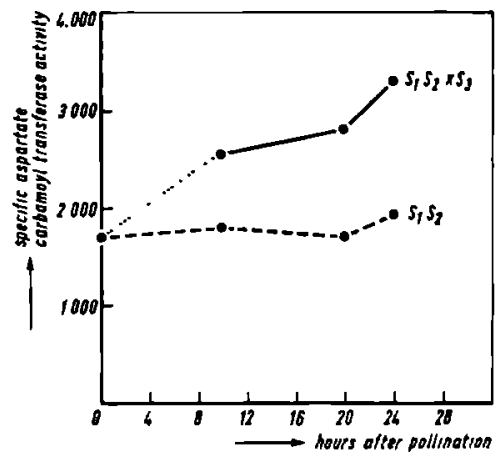

Fig. 7. Alteration in the activity of the specific aspartate carbamoyltransferase after cross-pollination.

Acta Bot. Neerl. 16(1), July 1967 


\subsubsection{Changes in aspartate carbamoyltransferase activity}

Fig. 7 illustrates that an activity increase of approximately $30-40 \%$ occurs for aspartate carbamoyltransferase following pollination.

One may wonder if the observed changes in enzyme activities are the consequence of the addition of the enzyme content of the pollen tubes or whether these activities can be imputed to a real alteration in activity of the combination style and tube. In order to check this, the enzyme activity was calculated per style and per 500 pollen tubes which represents the average number growing through this style.

3.3 Comparison of enzyme activities of the pollen alone, and the pollinated and the unpollinated styles

The absolute activity per style and per 500 pollen tubes of the different enzymes are presented in table 1 .

Table I. Comparison of the enzyme activities of unpollinated and pollınated styles with the activitıes of the $S_{3}$ pollen alone.

\begin{tabular}{|c|c|c|c|c|c|}
\hline & $\begin{array}{c}\text { enzyme acfiruties } \\
\text { per seyle }\end{array}$ & \multicolumn{2}{|c|}{$\begin{array}{l}\text { enzyme octivitiss } \\
\text { oer } 500 \text { oollen }\end{array}$} & $\begin{array}{c}\text { enzyme activities } \\
\text { por style }\end{array}$ & \multirow{2}{*}{$\begin{array}{c}\text { \% increase } \\
\text { of } \\
\text { enzyme } \\
\text { octivitios } \\
\text { after pollination }\end{array}$} \\
\hline enryme & $s_{1} s_{z}$ & ungerminated & $\begin{array}{l}\text { in vitro } \\
\text { oerminated } \\
\text { (4 hours) }\end{array}$ & $\begin{array}{c}S_{1} S_{2} \times S_{3} \\
\text { 20hours after } \\
\text { pollination }\end{array}$ & \\
\hline aced phosphotase & 0600 & 0067 & 0013 & 0670 & -21 \\
\hline $\begin{array}{l}\text { mose-1-phasehate } \\
\text { oldolese }\end{array}$ & $0090^{-}$ & 0001 & 8006 & $\begin{array}{l}- \\
0147\end{array}$ & 64 \\
\hline $\begin{array}{c}\text { alonime } \\
\text { eminotransforose }\end{array}$ & 0075 & $0001^{-}$ & 0003 & 0096 & 24 \\
\hline $\begin{array}{c}\text { aspartote } \\
\text { ominatranstorase }\end{array}$ & $\begin{array}{l}-1- \\
-\end{array}$ & 0009 & 8016 & $\begin{array}{r}0631 \\
--\end{array}$ & 10 \\
\hline SOH ORIA & 0036 & 0005 & 0001 & 0071 & 75 \\
\hline - & - & & & $\ldots-$ & -- \\
\hline GOH doomin & 0034 & - & 0003 & 0043 & 17 \\
\hline UOPGOH & 0001 & 0007 & 0007 & 0006 & 0 \\
\hline crtrate synthose & 0132 & 0002 & 0005 & 0187 & 3 \\
\hline - & - & & & -- & \\
\hline $\begin{array}{c}\text { asportate } \\
\text { corbemoyltensforase }\end{array}$ & 0020 & 0008 & 0010 & 0060 & 0 \\
\hline
\end{tabular}

It is apparent from table 1 that especially the enzymes of the carbohydrate metabolism, i.e. KPA and citrate synthase, display activities which are greater than the joint enzyme activities of the unpollinated styles plus the pollen tubes which are growing through it. AsAT and AlAT are 10 and $24 \%$ more active than can be ascribed to the increase of enzyme activities caused by the growth of the pollen tubes alone. The transfer of amino groups is rather great which 
can point to an active metabolism of amino acids. Of the examined enzymes, the increase in the activities of aspartate carbamoyltransferase and UDPGDH are explainable as the summation of the enzyme activity of the $S_{3}$ pollen in the $S_{1} S_{2}$ styles, and in these cases, there is no question of a ,real" increase of the activity in the pollinated styles.

The activity of the GDH amin. is strongly increased (75\%) after pollination which can point to enhancement of the glutamate synthesis. Despite the rather high activity of the acid phosphatases in the $S_{3}$ pollen, the activity of these acid phosphatases decreases $21 \%$ after pollination, so that the obvious activity in the style is reduced from $0.600+0.13=0.613$ to 0.470 . Thus, generally speaking, one can state that alterations in enzyme activities occur in pollinated styles which cannot be ascribed to a simple addition of pollen and style.

The enzyme activities of the intraspecific combination $S_{1} S_{2} \times S_{3}$ are not only an addition of activities of styles and $S_{3}$ pollen, but also the result of an interaction between the 500 pollen tubes and the conducting tissue of the style through which they are growing. One may wonder what the nature of this interaction is. In other words, why does the combınation $S_{1} S_{2} \times S_{3}$ differ from the sum of the parts, style tissue and pollen? To shed light on this question, the pollinated system $\left(S_{1} S_{2} \times S_{3}\right)$ was compared with the unpollinated system $\left(\mathrm{S}_{1} \mathrm{~S}_{2}\right)$ in the following ways:

$a$. the distribution of enzyme activities in different sections along the length of the style was examined before and after pollination;

$b$. and the course of the uptake of radioactive labelled amino acids into the style was studied before and after pollination.

3.4 Inquiry into the nature of the alterations which take place within styles after pollination

3.4.1 Distribution of different enzymes in the pollinated and unpollinated styles

\subsubsection{Distribution of the KPA activity in the style}

Fifty unpollinated styles and as many cross-pollinated styles 9 hours after pollination were analyzed. The specific activities (see 2.5.2) of the various parts of the style are shown in table 2.

Table 2. Distribution of the specific KPA activity in the style of Petunia before and after compatible pollination.

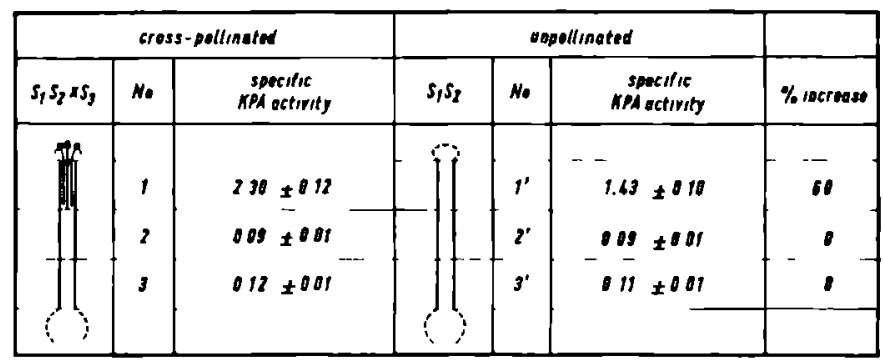


Table 3. Distribution of the specific AsAT activity in the style of Petunia before and after pollination with compatible pollen.

\begin{tabular}{|c|c|c|c|c|c|c|}
\hline \multicolumn{3}{|c|}{ eress-pollineted } & \multicolumn{3}{|c|}{ unpollinated } & \multirow[b]{2}{*}{$\%_{\text {sacroess }}$} \\
\hline$s_{1} s_{2} r s_{3}$ & Mo & $\begin{array}{l}\text { spoesifie } \\
\text { As AT ectivity }\end{array}$ & 5,5, & No & $\begin{array}{c}\text { spectific } \\
\text { AsAT ectivity }\end{array}$ & \\
\hline & I & $126 \pm 0.05$ & & $t^{\prime}$ & $115 \pm 0.02$ & 10 \\
\hline & 2 & $106 \pm 016$ & & $z^{\prime}$ & $138 \pm 003$ & $n$ \\
\hline & 3 & $282 \pm 005$ & & $y^{\prime}$ & $206 \pm 085$ & 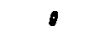 \\
\hline
\end{tabular}

One can conclude from table 2 that an increase of $60 \%$ in the KPA activity occurs only in that section of the style in which $S_{3}$ pollen has grown. Thus, there is no KPA reaction of the stylar tissue which is not yet in contact with the pollen tubes.

\subsubsection{Distribution of the AsAT activity in the style}

For the determination of the distribution of the activity, 50 unpollinated and 50 cross-pollinated styles 9 hours after pollination were taken. For the calculation of the measure of activity, see 2.5.3.

It is apparent from table 3 that not only $10 \%$ increase in the AsAT activity has taken place in that section of the style where the pollen tubes are in contact with the stylar tissue (compare no. 1 with no. 1'), but also an increase of $19 \%$ in the section of the style which the pollen tubes have not yet reached (compare no. 2 with no. $2^{\prime}$ ). In the lowest section, no increase of activity took place (compare no. 3 with no. 3').

\subsubsection{Distribution of the activity of the GDH amin. in the style}

In this experiment also, 50 unpollinated and 50 pollinated styles 9 hours after pollination were examined. The specific activity of the GDH amin. is expressed in values explained in 2.5.4.

An increase $(25 \%)$ in GDH activity takes place in the section of the style where pollen tubes are present (compare no. 1 with no. 1' in table 4). GDH is also activated $(13 \%)$ in the section of the style which the pollen tubes have not yet entered (compare no. 2 with no. 2 ' in table 4).

These results point to the fact that the interaction between the $S_{1} S_{2}$ style and the $S_{3}$ pollen tubes which grow through it are not necessarily restricted to the site of immediate contact between the pollen tubes and the style, at least so far as GDH amin. and AsAT are concerned. The increase in KPA only takes place where pollen tubes are present, thus on sites where an increased carbohydrate metabolism is needed and probably occurs. To obtain further insight into the increase in activities of the two amino acid transforming enzymes which occur in the section of the style which the pollen tubes have not yet entered, it was meaningful to compare the uptake of ${ }^{14} \mathrm{C}$-amino acids before and after pollination. 
Table 4. Distribution of the specific GDH amın. actıvity in the style of Petunia before and after pollınation.

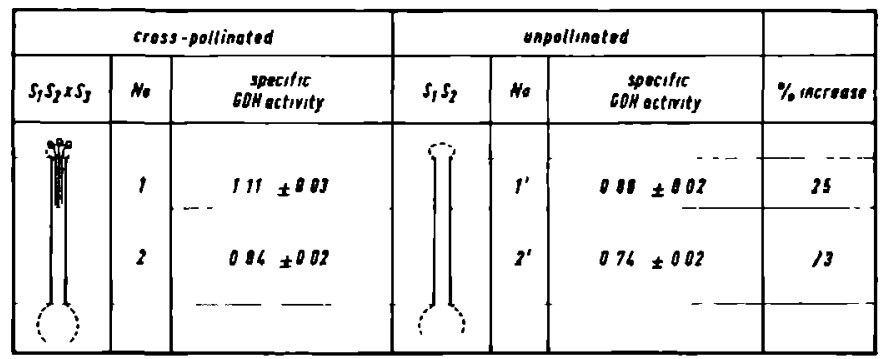

3.4.2 Course of the uptake of radioactive labelled amino acids in the style before and after pollination

It is apparent from $f g .8-11$ that the applied ${ }^{11} \mathrm{C}$-amino acids are taken up into the styles, for there is a rise in cpm in the crude extract, which is particularly high when the ${ }^{14} \mathrm{C}$-protein hydrolysate is offered $(f i g .11)$. This is probably caused by the removal of the corolla and sepals. However, the incorporation into proteins is not influenced by this removal, fig. 11 . There is no difference in uptake in the crude extract of ${ }^{14} \mathrm{C}$-threonine and ${ }^{14} \mathrm{C}$-leucine before and after pollination ( $f$ g. 8 and 9 ), but following pollination ${ }^{14} \mathrm{C}$-proline and ${ }^{14} \mathrm{C}$-protein hydrolysate $\mathrm{cpm}$ decrease ( $\mathrm{fg} .10$ and $\mathrm{II}$ ). Since pollen tubes normally utilize amino acids of the amino acid pool in the stylar tissue as substrate (TUPÝ 1961b), it is not surprising that the quantities of the easily metabolized proline and most other amino acids of the protein hydrolysate decrease after pollination, for these amino acids can be oxidized to $\mathrm{CO}_{2}$. The striking decrease $(40 \%)$ of ${ }^{14} \mathrm{C}$ proline in the crude extract as well as in the protein fraction after pollination can be ascribed, in addition to consumption in respiration, also to the incorporation into collagenlike proteins associated with pollen tube walls which are sedimented during the centrifugation and are consequently not counted (BRITIKOV c.s. 1965).

The incorporation of ${ }^{14} \mathrm{C}$-amino acids into proteins is indicated with dotted

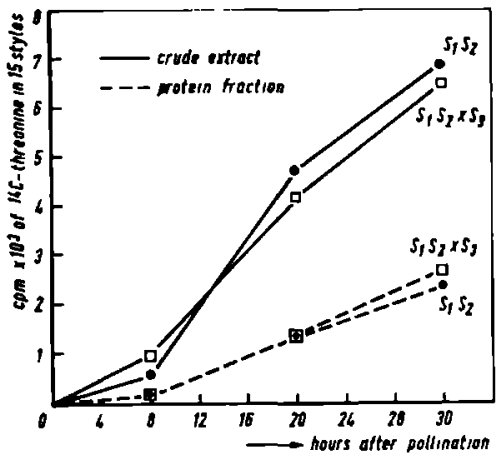

14
Fig. 8. Uptake of ${ }^{14} \mathrm{C}$-threonine into the crude extract and incorporation into the protein fraction of $15 S_{1} S_{2}$ and $15 S_{1} S_{2} \times S_{3}$ styles at various times after pollination.

Emasculated buds were placed in beakers with 2.0 $\mathrm{ml} \mathrm{H}_{2} \mathrm{O}-0.5 \mathrm{ml}{ }^{14} \mathrm{C}$-threonine $(0.05 \mathrm{mC}$ in $5 \mathrm{ml}$ $\mathrm{H}_{2} \mathrm{O}$ ). The styles were extracted with $1.2 \mathrm{ml} 0.05$ M TRA-buffer pH $7.72 \times 0.1 \mathrm{ml}$ of this extract was dried and counted in the GM tube. From the remaining $1 \mathrm{ml}$, the protein was precipitated with $3 \mathrm{ml}$ ice cold acetone. After dissolving again in 1 $\mathrm{ml}$ of the above-mentioned buffer, the dried samples were counted.

Acta Bot. Neerl. 16(J), July 1967 


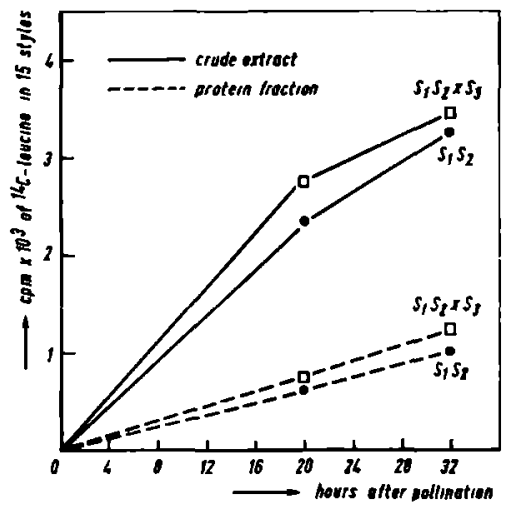

Fig. 9. Uptake of ${ }^{14} \mathrm{C}$-leucine into the crude extract and incorporation into the protein fraction of $15 S_{1} S_{2}$ and $15 S_{1} S_{2} \times$ $S_{3}$ styles at various times after pollınation. For the method, see legend fig. 8.

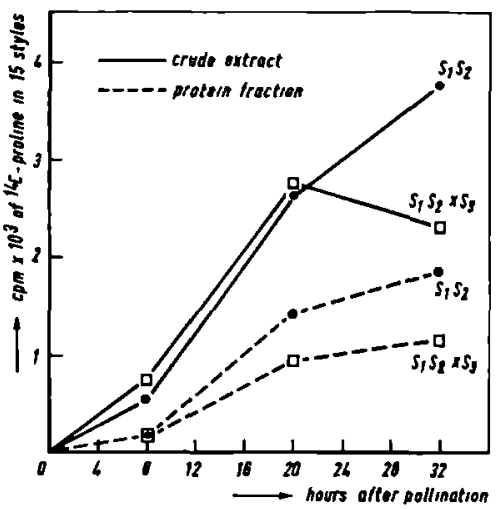

Fig. 10. Uptake of ${ }^{14} \mathrm{C}$-proline into the crude extract and incorporation into the protein fraction of $15 \mathrm{~S}_{1} \mathrm{~S}_{2}$ and $15 S_{1} S_{2} \times S_{3}$ styles at various times after pollination. For the method of determination, see legend fig. 8.

Fig. 11. Uptake of ${ }^{14} \mathrm{C}$-amino acids into the crude extract and incorporation into the protein fraction of $15 S_{1} S_{2}$ and $15 S_{1} S_{2} \times S_{3}$ styles al various times after pollination. The sepals were removed and the corclla was cut away to the point where the stamens arise. Pollen tubes did grow further after this treatment! Afterwards, these buds were placed in beakers with $1.3 \mathrm{ml} \mathrm{H}_{2} \mathrm{O}$ - $1.2 \mathrm{ml}{ }^{14} \mathrm{C}$-Chlorella protein hydrolysate $\left(0.05 \mathrm{mC}\right.$ in $\left.5 \mathrm{ml} \mathrm{H}_{2} \mathrm{O}\right)$. For further methods of extraction, proteın precipitation and counting, see legend fig. 8.

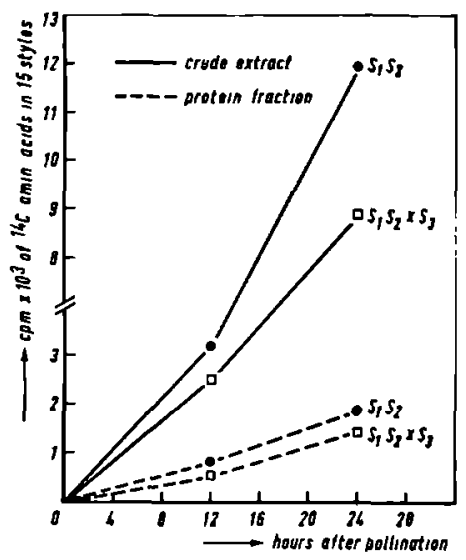

lines in figs. 8-11. The incorporation of the difficult to metabolize amino acids, namely threonine and leucine, is $10 \%$ greater after pollination which points to a protein synthesis (figs. 8 and 9). According to determinations of protein with the biuret method, the protein content is usually $10 \%$ greater after pollination using equal numbers of styles. This is not in agreement with the data of LiNSKENS \& TUPÝ (1966). They found a decrease of protein content after crosspollination. Presumably this discrepancy is due to the fact that they have not removed the stigmata. It is possible that the proteins of the ungerminated pollen might be decomposed. The incorporation of ${ }^{14} \mathrm{C}$-proline and ${ }^{14} \mathrm{C}$-protein hydrolysate is less after pollination which is attributed to the decomposition of these more easily metabolized amino acids. 
To this point, we have seen there is an interaction between pollen and styles, the nature of which is not yet clear. To clarify the situation for at least one case, GDH was studied in more detail to find out what happens to this enzyme after pollination. GDH was chosen for the following reasons:

1. the large increase in activity which occurs after pollination:

2. the important role of GDH in linking carbohydrate and amino acid metabolism;

3. the reliable and efficient methods of determination.

3.5 Nature of the changes in the GDH which take place after pollination and during the growth of the $S_{3}$ pollen through the $S_{1} S_{2}$ style

In order to trace how far the GDH in the unpollinated system may be compared with the GDH of the pollinated system, the concentrations of the enzyme extract, the substrate and the coenzyme are varied in turn.

\subsubsection{Comparison of the GDH amin. in unpollinated $S_{1} S_{2}$ styles and $S_{2} S_{2}$ styles} which are pollinated with $S_{3}$ pollen

\subsubsection{Variation of the amount of enzyme extract}

$50 \mathrm{~S}_{1} \mathrm{~S}_{2}$ and $50 \mathrm{~S}_{1} \mathrm{~S}_{2} \times \mathrm{S}_{3}$ styles were extracted 20 hours after pollination with $3 \mathrm{ml} 0.05$ TRA buffer pH $7.8+0.004$ EDTA. The extracts contained $1.75 \mathrm{mg}$ protein $/ \mathrm{ml}$ in both cases.

Fig. 12 shows that in both pollinated and unpollinated styles, the activity of the GDH is proportional to the enzyme concentration within the limits of the enzyme concentrations used in the experiments (namely: $0.1-0.4 \mathrm{ml}$ ).

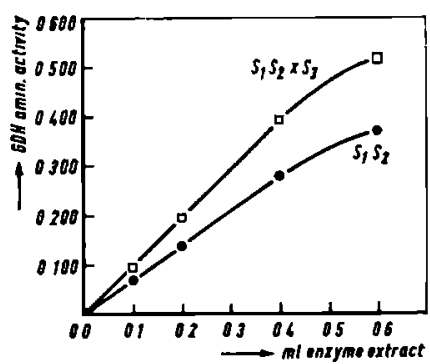

Fig. 12. Variation of the enzyme concentration in the GDH test in cross-pollinated and unpollınated and styles.

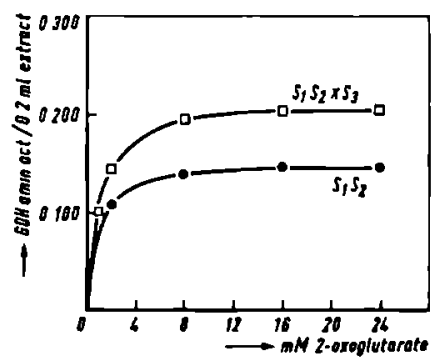

Fig. 13. Variation of the substrate concentration in the GDH test in $S_{1} S_{2}$ and $S_{1} S_{2} \times S_{3}$ styles.

\subsubsection{Variation of the substrate concentration}

$0.2 \mathrm{ml}$ extract was taken from 3.5.1.1 and the concentration of the 2-oxoglutarate was varied. Fig. 13 illustrates the hyperbolic form of the substrate curve in both pollinated and unpollinated styles. All further GDH enzyme tests were carried out with a $8 \mathrm{mM}$ 2-oxoglutarate solution, because with such a concentration, the GDH is saturated with substrate. 
Fig. 14. Variation of the coenzyme concentration in the GDH test in cross-pollinated and unpollinated styles.

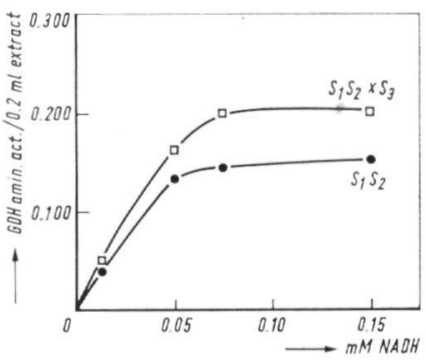

\subsubsection{Variation of the NADH concentration}

$0.2 \mathrm{ml}$ extract was taken from $3.5 .1 .1 ; 0.10 \mathrm{mM}$ NADH was always utilized for the GDH amin. enzyme test and as appears from fig. 14, this is precisely in the plateau region where obviously no more coenzyme is necessary to have the reaction proceed optimally. Furthermore, it was found that the GDH amin. exhibits a broad and flat $\mathrm{pH}$ optimum between 6.8 and 8.3 . No oxidoreductase reaction took place with $\mathrm{NADP}^{+}$and $\mathrm{NADPH}$ and no alanine dehydrogenase could be observed.

Enzyme, substrate and coenzyme were varied for the GDH deamin. also. It was found that the same conditions were given with GDH deamin. as with the GDH amin. test discussed above.

Now that it is clear that the measured activities are a suitable parameter for the amount of enzyme, the GDH activities in $\mathrm{S}_{1} \mathrm{~S}_{2}$ styles can be compared with each other before and after cross-pollination and it is meaningful to proceed with research into the nature of the increase in activity of the GDH.

3.5.2 Fractionation of $\mathrm{S}_{1} \mathrm{~S}_{2}$ and $\mathrm{S}_{1} \mathrm{~S}_{2} \times \mathrm{S}_{3}$ styles with ammoniumsulphate; fractions tested for the GDH amin. activity

0.6760 gr fresh weight of $\mathrm{S}_{1} \mathrm{~S}_{2}$ and $\mathrm{S}_{1} \mathrm{~S}_{2} \times \mathrm{S}_{3}$ styles (20 hours after pollination) were used in this experiment. The extraction was carried out with $5 \mathrm{ml} 0.05 \mathrm{M}$ TRA buffer $\mathrm{pH} 7.8+0.004 \mathrm{M}$ EDTA. The protein fractions precipitated with different ammoniumsulphate concentrations were dissolved in $2 \mathrm{ml}$ extraction buffer and were dialyzed against the same buffer for 12 hours at $4^{\circ} \mathrm{C}$. After

Fig. 15. Distribution of the specific GDH amin. activity of different ammonium sulphate fractions of unpollinated and cross-pollinated style extracts.

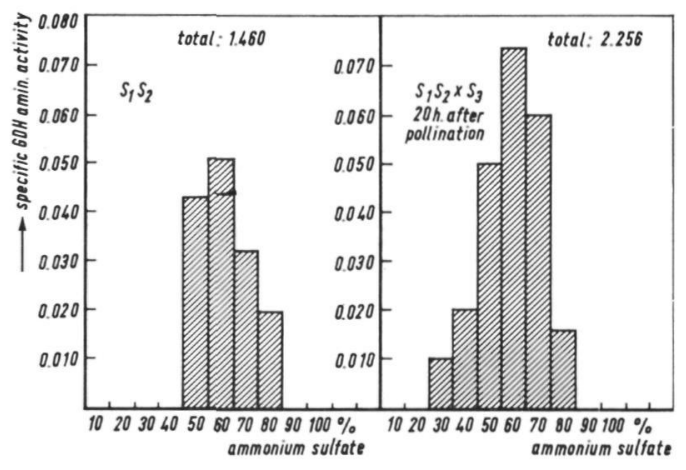

Acta Bot. Neerl. 16(1), July 1967 
dialyzing, $0.5 \mathrm{ml}$ was used for the GDH test and the protein content was determined. The distribution of specific activity over the different fractions is shown in fig. 15. The measure of activities is expressed as mentioned in 2.5.1.

The sum of the specific activities of the different fractions is much greater after pollination than before, and it is, moreover, apparent that the distributions of the various fractions differ. That is to say, a GDH activity is present in the 30 and $40 \%$ ammoniumsulphate precipitate from pollinated styles which is lacking in unpollinated styles. The results pointed to an alteration of GDH. Therefore, another separation was carried out employing a more refined fractionation technique.

3.5.3 Chromatography of unpollinated and cross-pollinated style extracts on DEAE-cellulose; GDH amin. test on the fractions

This experiment was carried out three times according to 2.7 with the same result. The distribution of the activity of GDH amin. in the different fractions of one experiment is expressed in the figs. 16 and 17.

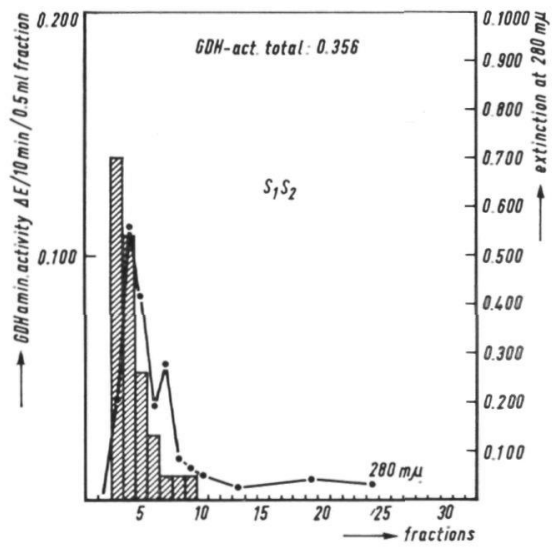

Fig. 16. GDH activities after chromatography on DEAE-cellulose of unpollinated style extract.

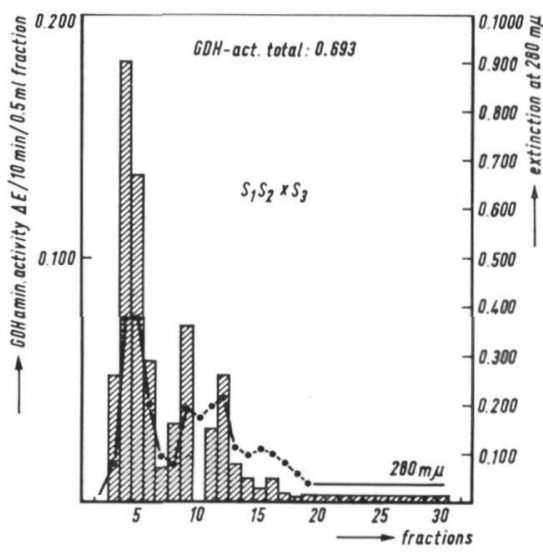

Fig. 17. GDH activities after chromatography on DEAE-cellusose of cross-pollinated style extract ( 20 hours after pollination).

Comparing figs. 16 and 17, it is striking that the total activity of the GDH is greater after pollination than before and, moreover, that the GDH activities are localized in the fractions 3-9 after fractionation of the $\mathrm{S}_{1} \mathrm{~S}_{2}$ styles, whereas the GDH activity is distributed over many fractions after pollination. This affirms to the results of the former experiment indicating that the enzyme activities of the GDH amin. cannot be accounted for by the same protein.

In order to gather further information about the differences between the GDH proteins, they were separated electrophoretically followed by coloring of the GDH active regions. 


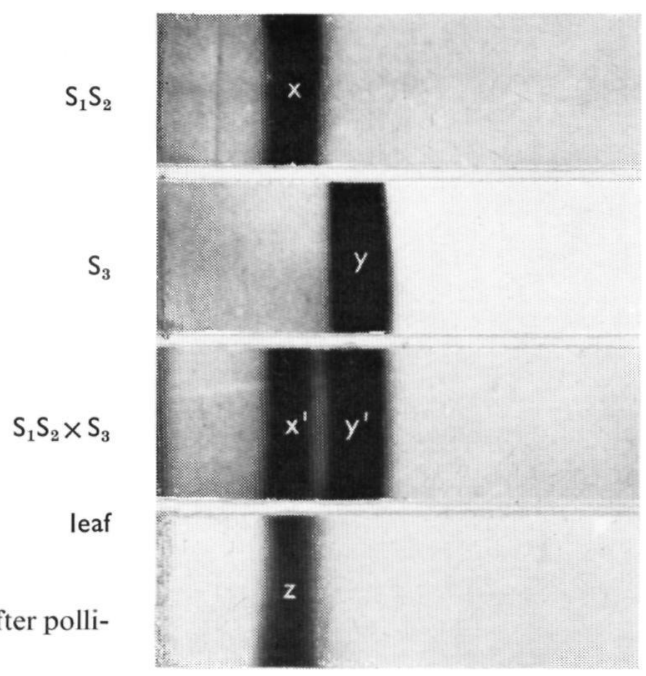

Fig. 18. Alteration of the GDH pattern after pollination.

3.5.4 Comparison of the activity of GDH in pollinated and unpollinated styles after electrophoretical separation

The method of the polyacrylamide electrophoresis and the coloring of the GDH with nitro-bluetetrazolium were described in 2.8. Following coloring, sharp violet bands are visible in the gel at the sites of GDH activity.

Fig. 18 shows photographs of GDH bands in gels. Unpollinated styles and pollen alone have only one band, $x$ and $y$ respectively, whereas the pollinated styles have two bands, x' and y'. The extra band y' which appears in the style after pollination arises from the pollen, since it is observed that a mixture of unpollinated style extract and pollen extract produces the same pattern after electrophoresis as found in pollinated styles. The band $\mathrm{z}$ of the leaf extract is comparable with the band $x$ of the unpollinated style. The GDH of the $\mathrm{S}_{3}$ pollen is not the same as the GDH of the $S_{1} S_{2}$ plant and for that reason, one is justified in considering these as isoenzymes. The results of the previous fractionation experiments, section 3.5.2 and 3.5.3 can be explained against this background.

Another experiment as presented in table 5 has shown that in pollinated

Table 5. Intensities of the GDH bands at various times after pollination, expressed as proportion in weights of the curves, after extinction writing of the gel-photographs.

\begin{tabular}{|c|c|c|c|c|c|}
\hline \multirow{2}{*}{$\begin{array}{c}\text { hours after } \\
\text { pollination }\end{array}$} & \begin{tabular}{c} 
unpollinated \\
\cline { 2 - 4 }
\end{tabular} $\begin{array}{c}\text { intensity of } \\
\text { band } x\end{array}$ & $\begin{array}{c}\text { pollentensity of } \\
\text { band } x^{\prime}\end{array}$ & $\begin{array}{c}\text { intensity of } \\
\text { band } y^{\prime}\end{array}$ & $\begin{array}{c}\text { \% increase } \\
\text { of band } x^{\circ}\end{array}$ & $\begin{array}{c}\text { total increase } \\
\text { in \% }\end{array}$ \\
\hline 6 & 1922 & 1615 & 315 & -26 & -10 \\
12 & 2002 & 1985 & 365 & 0 & 17 \\
22 & 2077 & 2720 & 1328 & 31 & 94 \\
30 & 2105 & 2525 & 1043 & 20 & 69 \\
\hline
\end{tabular}


extract the intensity of the extra GDH band y' exhibits an increase with a maximum at 22 hours after pollination i.e. when pollen tubes have covered $2 / 3$ the length of the style. After a preliminary decrease the band $x$ ' shows also a higher intensity after 22 hours.

It is possible to extract the GDH out of the gels by homogenizing with buffer. One series of gels was colored for GDH to determine the areas to be extracted. These bands were then sliced and extracted from uncolored gels. With this method the previous experiment is affirmed for the GDH in both directions for 22 hours after pollination. It was also observed that both GDH deamin. and GDH amin. are localized in the same bands. At the reference site $\mathrm{z}^{\prime}$ (see table 6) no GDH activity could be demonstrated.

An important problem is to ascertain if this extra GDH band y' and the increase in intensity of band $x^{\prime}$ are a consequence of a de-novo synthesis or whether the pollen enzyme brings this about. To investigate this, ${ }^{14} \mathrm{C}$-leucine was incorporated into proteins of pollinated and unpollinated styles which were extracted and estimated for labelling in the GDH bands.

3.5.5 Protein separation with disc electrophoresis after incorporation of ${ }^{14}$ C-leucine

Thirty $S_{1} S_{2}$ and as many $S_{1} S_{2} \times S_{3}$ buds (20 hours after pollination) were placed in beakers filled with $3 \mathrm{ml} \mathrm{H}_{2} \mathrm{O}+1.5 \mathrm{ml}{ }^{14} \mathrm{C}$-leucine solution $(0.01 \mathrm{mC}$ in $5 \mathrm{ml} \mathrm{H}_{2} \mathrm{O}$ ). After extraction with $0.05 \mathrm{M}$ TRA buffer $\mathrm{pH} 7.8$ (see 2.3) protein was precipitated with ice cold acetone $(75 \%)$ and the precipitate was dissolved in $0.6 \mathrm{ml}$ extraction buffer. This protein solution was separated on 5 gels. After coloring the GDH, the bands were sliced out and counted as described 2.8.1.

Table 6 shows that $41 \%$ more ${ }^{14} \mathrm{C}$-leucine is incorporated into band y' than into the corresponding region $z^{\prime}$. This difference varied from $35-41 \%$ in three experiments. This means that there is a de-novo synthesis of the extra GDH band y' caused by the growth of the pollen tubes.

Table 6. Incorporation of ${ }^{14} \mathrm{C}$-leucine into the $\mathrm{GDH}$ of unpollinated and cross-pollinated styles ( 20 hours after pollınation).

\begin{tabular}{|c|c|c|c|c|}
\hline \multirow{2}{*}{$\cos / 3 t$ stylos } & \multicolumn{2}{|c|}{$58 H$ bands in peis } & \multirow{2}{*}{ con $/ 30$ styles } & \multirow{2}{*}{$\begin{array}{c}\text { diffunnee } \\
\text { in \% }\end{array}$} \\
\hline & $W 166 \mathrm{~K}$ & $6100 \mathrm{~K} \times 120$ & & \\
\hline 1030 & 】 & $x^{\prime}$ & 1015 & 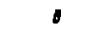 \\
\hline 1936 & & & 2721 & 61 \\
\hline
\end{tabular}

This is almost in quantitative agreement with the data given in table 5 , where there was an increase of $49 \%$ in the intensity of the band y' (with regard to band $\left.x^{\prime}\right)$. In all experiments, there was no difference in cpm between band $x$ and $x$, whereas an increase in intensity of $31 \%$ was observed (see table 5 ). This can 
mean that perhaps under the influence of pollen tube growth, transformations in the conformations of the GDH take place which result in an activation.

Further inquiries were directed to a possible occurrence of an activation.

\subsection{Studies concerning the activation of the GDH}

With the extraction method employed a disruption of the mitochondrial system is brought about and the GDH appears in solution (DIXON \& WEBB 1964). When an extract is made of cross-pollinated styles, the GDH of the stylar tissue (band $x^{\prime}$ ) and the GDH band of the pollen tubes (band $y^{\prime}$ ) are released together. It is not likely that the activation of GDH is caused by association of the two GDH's, since after electrophoretical separation band $x$ ' remains highly active. The increase in activity of band y' has to be ascribed to de-novo synthesis.

Attempts were made to imitate the activation by combining the style and pollen extracts.

3.6.1 GDH activities before and after combination of the style extract and the pollen extract

It is clear from fig. 19 that the GDH deamin. is proportional within limits to the enzyme concentration for both the pollen and the style extract. Thus, it might be expected that in the combination of these two extracts, the GDH activity would be the sum of the separate activities, but it is clear from fig. 20 that the measured GDH deamin. activities are twice as large as those expected at particular concentrations of extract. It is likely that an activator is involved which causes the activation of the GDH deamin. This activator seems to have a protein nature, because after dialysis of the extracts ( 14 hours at $4^{\circ} \mathrm{C}$ ), this activation remains present.

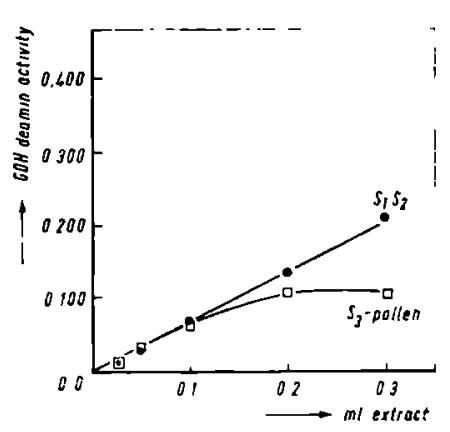

Fig. 19. GDH deamin. activities of different quantities of style and pollen extract. $40 \mathrm{~S}_{1} \mathrm{~S}_{2}$ styles and $25 \mathrm{mg}$ pollen are extracted with 2 $\mathrm{ml}$ buffer according to 2.3 .

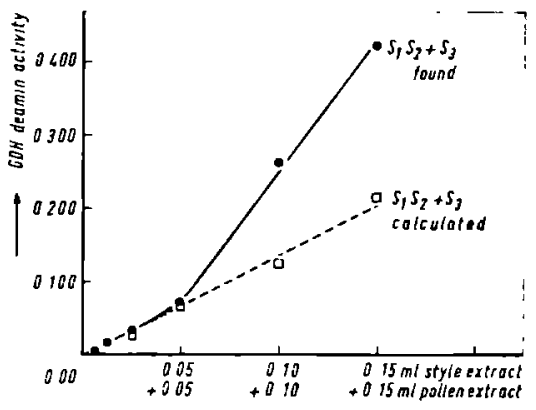

Fig. 20. GDH deamin. activities artci combination of the pollen with the style extract.

Activation appears also after combination of the pollen extract with the extract of the cross-pollinated styles, but not after combining the unpollinated with the cross-pollinated extract. Following combination of pollen with style 
extract, the GDH amin. activity is the sum of the parts. In other words the activation only takes place in the direction of the deamination and probably is due to a protein-protein interaction that results in an activation.

The effect of temperature on the velocity of enzyme reactions gives information about the stability of the enzyme. From this point of view, it was interesting to investigate the effect of preincubation on GDH in both directions and after combination of the pollen with the style extract.

3.6.2 Effect of preincubation at $60^{\circ} \mathrm{C}$ on the GDH in both directions and on the combination of the pollen and style extract of the GDH deamin.

In general, one may say that the activities of the GDH decrease after preincubation at $60^{\circ} \mathrm{C}$ (see fig. 21,22 and 23 ). It is obvious from fig. 21 and 22 that the decrease of the GDH activities is greater in both directions after cross-pollination.
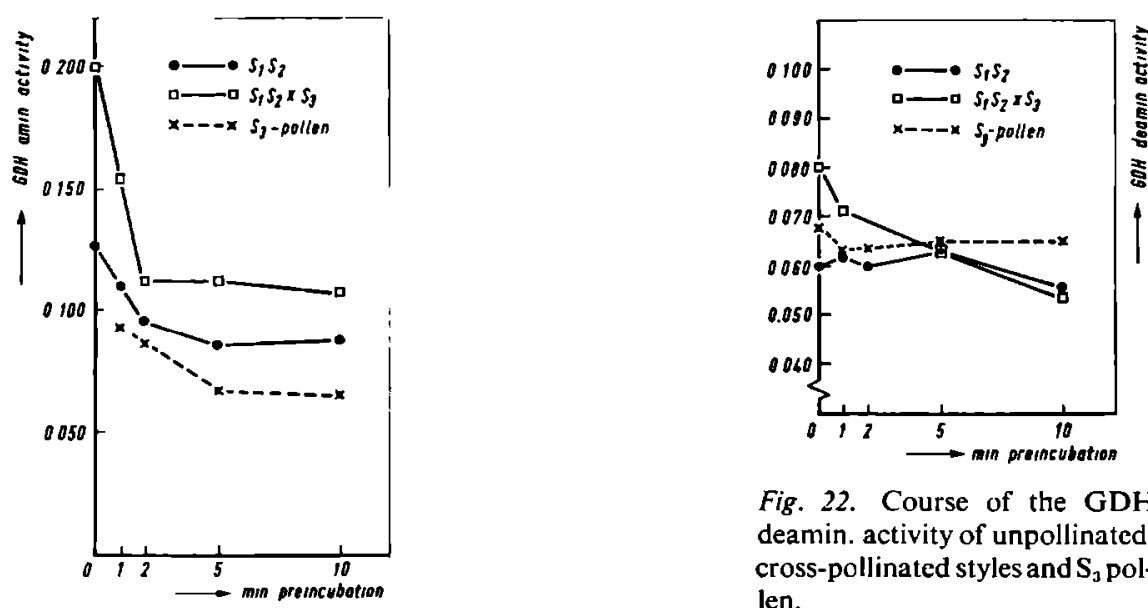

Fig. 22. Course of the GDH deamin. activity of unpollinated, cross-pollinated styles and $S_{3}$ pollen.

Fig. 2I. Course of the GDH amin. activity of unpollinated, cross-pollinated styles and $S_{\mathbf{a}}$ pollen.

The stability of a part of the GDH is less after pollination because 2 to $5 \mathrm{~min}$ after preincubation the values for the GDH activities have dropped to nearly the same level as the unpollinated style extracts. The same may be concluded from fig. 23 namely, after an initial activation effect of the extracts upon each other, nothing is left after $5 \mathrm{~min}$ incubation and the measured values are equal to the calculated ones.

It is likely that the activated $\mathrm{GDH}$ after 5 min preincubation at $60^{\circ} \mathrm{C}$ changes into the non-activated conformation. The non-activated GDH seems to be more heat stable.

It is now probable that an activation of the GDH occurs. To study the mechanism of this activation, further stylar extract was fractionated by means of column chromatography, after which the fractions were checked for activation by adding pollen extract. 
Fig. 23. GDH deamin. activity after combining pollen with style extracts.

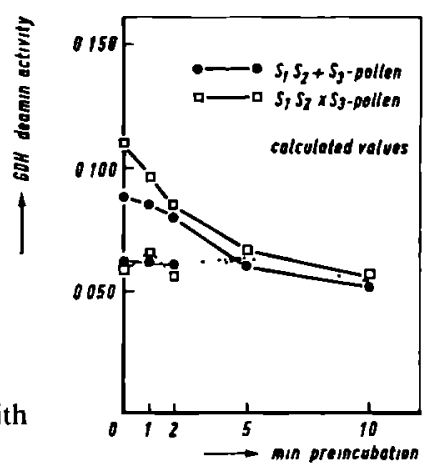

3.6.3 Fractionation of stylar extract on a Sephadex G 200 column; test for $\mathrm{GDH}$ in both directions

This experiment was carried out as described in section 2.2.6. For the activation test, 0.05 and $0.1 \mathrm{ml}$ pollen extract ( $35 \mathrm{mg}$ in $2.5 \mathrm{TRA}$ buffer) is combined with $0.5 \mathrm{ml}$ of each fraction of style extract.

It appears from $f i g .24$ that the GDH amin. and deamin. are the same enzyme, and moreover, that after combination with pollen extract, an activation with two maxima takes place.

The sum of the calculated GDH deamin. activities of the fractions ( $\Delta \mathrm{E} / 20$

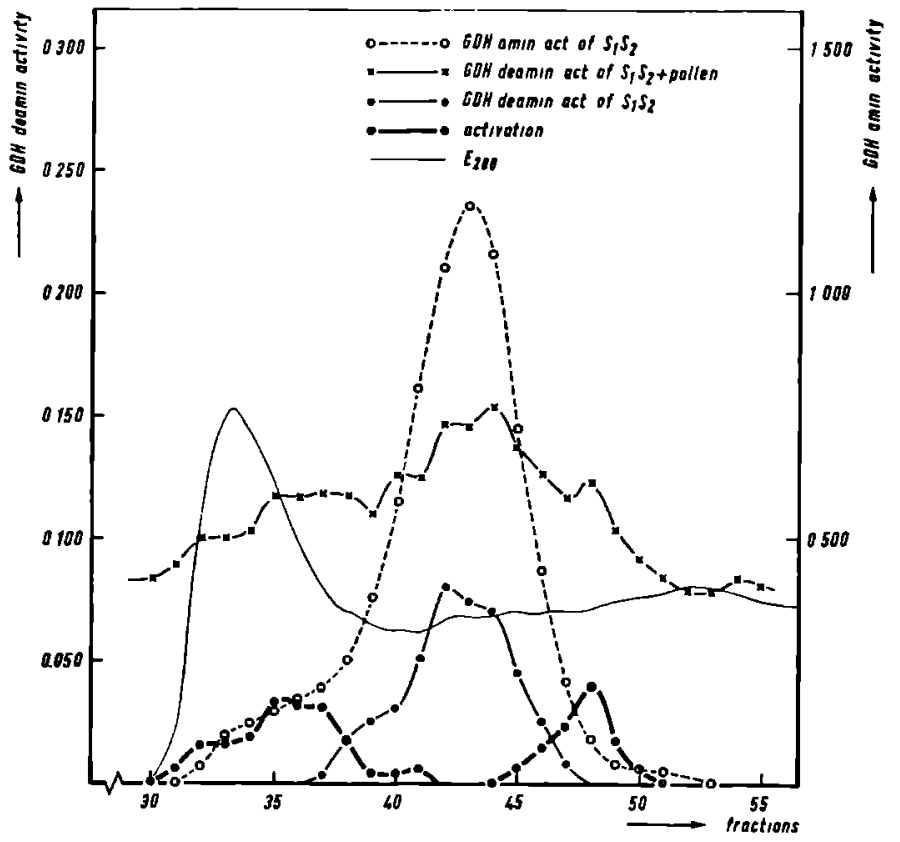

Fig. 24. Chromatography of stylar extract on Sephadex G 200; test for GDH in both directIons and activation of GDH deamin. after adding pollen extract. 
$\mathrm{min} / 0.5 \mathrm{ml})$ and of the pollen extract $(\Delta \mathrm{E} / 20 \mathrm{~min} / 0.1 \mathrm{ml})$ is 2.110 , but the measured activity is 2.353 which is $12 \%$ higher. In the reverse experiment in which pollen extract is fractionated and activation is checked with the stylar extract, no activation could be observed. It is likely to conclude that the activator is localized in the pollen extract. This is also indirectly affirmed since there is no difference of the activation of GDH deamin. after combination 0.05 and $0.1 \mathrm{ml}$ pollen extract with $0.5 \mathrm{ml}$ fractionated style extract. Now one may subtract the GDH deamin. activities of the pollen in the previous experiment.

The measured total GDH deamin. activity is 0.713 and the calculated total activity is 0.470 . This means an activation of $52 \%$. According to section 3.6.1, the activation should have to be $100 \%$, but $50 \%$ is lacking. Presumably this can be ascribed to a suppression of the activation by high enzyme concentrations; hence the low activation values in the fractions 39 to 46 and even negative values for the fractions 42 and 43 of -0.017 and -0.011 respectively.

\section{DISCUSSION}

\subsection{Interaction of pollen tube and style at the metabolic level}

The experiments reported here elucidate aspects of the complex metabolic relation between the growing pollen tubes and the conducting tissue of the style during the progame phase.

This study is intentionally restricted to the compatible relation, because this is the case which leads to successful fertilization and offers fewer experimental difficulties than the incompatible combination. At the same time these experiments are for purposes of comparison a necessary preparation for further investigations into incompatible relations between style and pollen tubes.

The results represent the first information concerning the metabolic action of enzyme systems imported by the growing pollen tubes upon the enzymes and substrates present in the style. They complement and extend earlier observations obtained by histochemical methods (HAECKEL 1951 ; BRITIKOV 1954; SCHLÖsSER 1961) and by interpretation of microscopical and electron microscopical observations (Schoch-Bodmer \& Huber 1947; van der Pluym \& Linskens 1966). An important discovery is that both systems (pollen tubes and styles) manifest the consequences of interaction prior to the syngamy in its strictest sense before genetic material comes into contact.

Already in the progame phase male and female material meet each other and this association requires a coordination at the metabolic level to complete the steps necessary for bringing the male cells into the embryo sac.

As it is the intention of this investigation to examine the situation during the growth of the pollen tubes, the initial phase of pollen germination on the surface of the stigma is excluded by removing the stigmata. The analyses of the processes during the first hours are excluded, although in this initial phase several processes take place since it is known that within a few minutes after contact with the stigma surface, enzymes in the pollen grain are activated (STANLEY \& Linskens 1964). There is a passage of a complex of enzymes from 
the pollen to the stigma (OSTAPENKo 1960). The enzymes are easily released from the sporoderm (STANLEY \& LiNSKENS 1965; MäKINEN \& BREWBAKER 1967) and it has become clear that the coat of the pollen grain is a living and physiologically active structure (Zinger \& Petrovskaja-Baranova 1961). Although there may be an activation in the stigma during the first $\mathbf{4}$ hours, it is not very likely that increases in enzyme activities occur in the whole style because analyses carried out within 4 hours after pollination do not show differences with regard to the unpollinated styles. Our observations, therefore, concern exclusively the growth of the pollen tubes, not the germination and penetration phase into the stigma. The stigmata are removed in all experiments for the following reasons:

1. The stigma exudate consists primarily of oily substances (KonAR \& LiNsKENS $1966 a$, b) which leads to turbidity in the extract.

2. The stigmata are abundantly pollinated to ensure that the maximum number of pollen tubes $(400-500)$ will grow through the style. By removing the stigmata, the bulk of ungerminated pollen grains and the pollen tubes which have grown only in the stigma tissue are not included in the extract.

\subsection{Alterations in enzyme activities during the growth of the pollen tubes through the style}

Except for the acid phosphatases all the examined enzymes show a greater activity after pollination. Increases in activity reflect the metabolic consequence to the style of the encounter of growing cells (pollen tubes) with a fully developed tissue (style).

\subsubsection{Decreasing activity of acid phosphatases}

The activity of acid phosphatases decreases in contrast with the other enzymes checked. No alkaline phosphatases are present either in the pollen or in the styles of Petunia although GórsKa-BryLASs (1965) did find them in the pollen of different plant species. However, acid phosphatases are present in high activity which is in accordance with histochemical data of HAECKEL (1951) and PoDduBnaYA-ARNOLDI c.s. (1961).

On the other hand BeLLaRTZ (1956) was not able to demonstrate acid phosphatase activity in Petunia pollen and SCHLÖsSER (1964) could only detect a slight activity. This may be due to the determination methods applied by the authors. The function of the acid phosphatases is not yet understood, but the observed decrease after pollination may be of interest for further studies.

\subsubsection{Enzymes with an increased activity}

The tested enzymes which showed a greater activity after pollination are enclosed in boxes in the scheme ( $f$ ig. 25). The increases in activity of UDPGDH and aspartate carbamoyltransferase can be ascribed to the activity contributed by the growing pollen tubes alone (dotted lines) which is observed also in vitro. The activity of these two enzymes in the pollen is very great compared with the activity in the style (table I). Aspartate carbamoyltransferase plays an impor- 


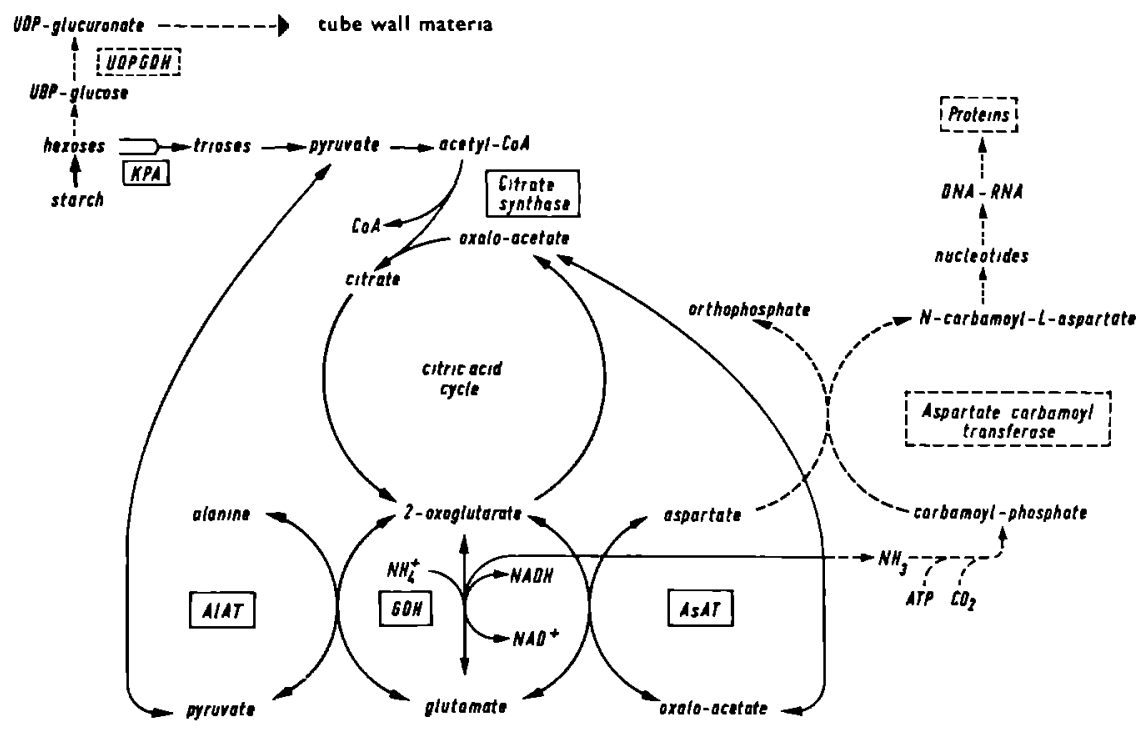

Fig. 25. Metabolic pathways involving some of the investıgated enzymological steps in pollinated styles of Petunia hybrida.

Checked enzymes are placed in rectangles. The dotted lines indicate the reactions which can be ascribed mainly to the growth of the pollen tubes.

tant role in protein synthesis. The catalytical action of the UDPGDH is indispensable for the synthesis of tube wall material.

One can conclude from incorporation experiments with ${ }^{14} \mathrm{C}$-leucine and ${ }^{14} \mathrm{C}$-threonine ( $\mathrm{fg} .8$ and 9 ) that a protein synthesis of approximately $10 \%$ does take place, and it is pointed out for the case of GDH that this protein is synthesized de-novo by the pollen. In growing pollen tubes a synthesis of RNA occurs as was shown by incorporation of ${ }^{3} \mathrm{H}$-uridine (TANO \& TAKAHASHI 1964; MASCARENHAS 1965). Thymidine is incorporated into the tube nucleus as well as into the generative nucleus (TAKATS 1965). This observation led to the hypothesis that a growing cell like a pollen tube has to synthesize a certain amount of DNA to make RNA templates and via this latter new enzymes (STANLEY \& YouNG 1962).

The high activity of aspartate carbamoyltransferase, the enzyme that catalizes the first step to pyrimidine synthesis, and the fact that the de-novo synthesis of the GDH occurs in the pollen tubes, give evidence that the hypothesis of Stanley \& Young (1962) can be applied also to the in vivo situation, at least concerning RNA synthesis. The increase in enzyme activities of the carbohydrate metabolism viz. the ketose-l-phosphate aldolase (KPA) and the citrate synthase may be expected, because it has already been found that after pollination an increased oxygen consumption takes place (LINSKENS 1955) and the 
amount and composition of starch and free sugars alters (LINSKENS 1955; TUPÝ 1961a; PYL'NEv 1962). For sufficient encrgy for the growth of the pollen tubes, decomposition of sugars via glycolysis and the citric acid cycle has to take place.

The GDH amin. activity is strongly increased $(75 \%)$ after pollination which means that inorganic nitrogen is bound to 2-oxoglutarate which gives rise to glutamate. This step is coupled with two amino transferases AsAT and AlAT. Both enzymes are able to form other amino acids by transaminating glutamate. After pollination there is an increase in the activities of AlAT and AsAT of 24 and $10 \%$ respectively. Thus, an increased amino acid transformation occurs which is attended by protein turn-over and synthesis, as is indicated by incorporation experiments with ${ }^{14} \mathrm{C}$-amino acids. The specific activity of AsAT is about 15 times greater than the activity of AlAT; but this is not surprising since high activity of AsAT is generally found in plants (DAvIES c.s. 1964). In fresh and preincubated $\left(30 \mathrm{~min}\right.$ at $25^{\circ} \mathrm{C}$ ) extracts of pollinated and unpollinated styles the activity of the GDH amin. is equal to the activity of the GDH deamin. Following dialysis and chromatographic and electrophoretic separation, however, the activity of GDH amin. remains constant whereas the GDH deamin. activity decreases, so that the ratio GDH amin./GDH deamin. becomes greater than 6 (compare table 1 with $f i g$. 24). In kinetics studies with pure GDH one finds that the equilibrium always favors glutamate production (DAviES c.s. 1964). It is possible that through the purification procedure a partial de-activation of the GDH deamin. takes place which may be caused by the removal of small molecules or ions, perhaps pyridoxalphosphate or zinc ions which are known to be essential for the catalitical action of the GDH. It is not very likely that a dissociation of the GDH occurs as is stated by several authors (see the review of FRIEDEN 1963) because no alanine dehydrogenase activity could be observed. Most significant is that certain of these alterations in enzyme activities are not only restricted to the place in the style where pollen tubes are growing. There seems to be an activation wave in front of the growing pollen tubes in the style.

\subsection{The front wave advancing the growing pollen tubes}

The interaction experiments (table 2) with KPA have shown that the increased carbohydrate metabolism is present only in sections where pollen tube growth occurs.

Contrary to this the GDH and AsAT already show an increase in activity in that section of the style where the pollen tubes have not yet grown (see table 3 and 4). This means that there has to be an exchange of substances between the growing pollen tubes and the styles which was demonstrated earlier (SCHOCHBODMER \& HubEr 1947; LinsKens 1955; LinsKens \& ESSER 1959). Under the influence of the growing pollen tubes the styles prepare the way for them by changing metabolic pathways and switches of exogenous metabolism in styles. They ,pave" the way by solving middle lamella material and by delivering substrates for energy and wall synthesis (LiNSKENS \& EsSER 1959). There is a release of co-factors and an adaptation of metabolic pathways takes 
place (STANLeY 1958). It is possible that a chemotropical gradient is formed by the interaction that precedes the growth of the pollen tubes in the style. In this context GDH may function as a key enzyme since it catalizes the reaction which links amino acid and carbohydrate metabolism. In the following section the behavior of this important enzyme during the pollen tube growth is further discussed.

\subsection{Activation and de-novosynthesis of GDH after pollination}

The GDH of plants seems to have quite different properties than GDH of animal sources. It is, for instance, not influenced by purine nucleotides (FrIEDEN 1965). Petunia GDH is active only with NAD $^{+}$(see 3.5.1.3; FrIEDEN 1963) and is inhibited by p-chloromercuribenzoate (HELLERMAN c.s. 1958; SANWAL 1961) which indicates that protein sulfhydryl groups are required for activity.

Composition of enzymes is known to be controlled by genes. In the investigated combination $S_{1} S_{2}$ and $S_{3}$ the pollen originate from another Petunia clone, thus probably under the control of different genes. The GDH of the $S_{3}$ pollen has other electrophoretical properties than the GDH of $S_{1} S_{2}$. It has become clear that GDH of $S_{1}$ and $S_{2}$ pollen is identical with that of the $S_{1} S_{2}$ plant, since a mixture of $S_{1}$ and $S_{2}$ pollen extract and $S_{1} S_{2}$ style extract shows only one GDH band in the gels. The study of cross-pollination between these two clones is consequently very appropriate for seeking further insight into the enzyme alterations as a result of pollination!

From this report it has become evident that after pollination a de-novo synthesis of the GDH of the pollen tubes takes place. Of course one cannot generalize. One must be careful in saying that the extra increases of all enzyme activities after pollination can be ascribed to the de-novo synthesis of pollen enzymes. However, this does seems likely as far as UDPGDH and aspartate carbamoyltransferase are concerned.

There is a discrepancy of about $15 \%$ between the measured increase of GDH amin. activity and the increase that can be ascribed to the incorporation of ${ }^{14} \mathrm{C}$-leucine. This is a result of the fact that the un-labelled amino-acid pool (LinsKeNS \& TUPÝ 1966) present in the style and also the decomposed style proteins can be used by the pollen, since it is demonstrated that the new proteins can be produced using style amino acids and proteins (LiNSKENS 1958; 1959, 1964b). The results obtained with GDH suggest that apart from the increase in enzyme activities an interaction effect between pollen tubes and style occurs. The GDH of the style is activated under the influence of a high molecular substance presumably a protein or RNA-like substance of the pollen tubes. Proteins and RNA can alter the configuration of the enzyme molecule, thus affecting its catalitic activity (NICHOL c.s. 1964) as was demonstrated for GDH by Roberts (1966) and Holzer \& HierHOLzer (1963). 


\section{REFERENCES}

Bellartz, s (1956) Das Pollenschlauchwachstum nach arteıgener und artfremder Bestaubung eınıger Solanaceen und die Inhaltstoffe ıhres Pollens und ihrer Griffel Planta (Berl) 47 588-612

BRITIKOV,E A (1956) On the physıological-bıchemıcal analysıs of pollen germination and the growth of pollen tubes in pistıl tissues Trudy Timirjaseff Inst Plant Physiol Acad Nauk SSSR 8(2) 3-58

- S V VLADimiRtseVA \& N A musatova (1965) Transformation of prolıne in germınatıng pollen and pistıl tissues Physiol Rastemı 12:953-967

DAVies, D D, J Giovanelli \& T AP REes (1964) Plont Biochemistry in W O James (ed) Bot Monogr 3: 366 Blackwell sci Publ Oxford

DAvis, B J (1964) Disc Electrophoresıs-II Method and application to human serum protcins Ann NY Acad ScI 121:404-427

DIXON, M \& E C WEBB (1964) Enzymes 634 Spottiwoode, Ballantyne and Co Ltd London and Colchester, 2nd ed

FRIEDEN, C (1963) L-glutamate Dehydrogenase, in Boyer, P D, H LARdy \& K MYRBaCK The Enzymes 7: 3-24 Acad Press New York, London

- (1965) Glutamate Dehydrogenase VI Survey of purıne nucleotıde and other cffects on the enzyme from various sources $J$ Biol Chem 240: 2028-2035

GERHART, J C \& A B PARDEE (1962) The enzymology of control by feed back inhibition $J$ Bıol Chem 237:891-896

GORNALL, A G, C S BARDAWIL \& M M DAVID (1949) Determination of serum proteins by means of the bıuret reaction $J$ Biol Chem 177: 751-766

GoRSKA BRYLASS, A (1965) Hydrolases in pollen grains and pollen tubes Acta Soc Bot Pol 34: 589-604

HAECKel, A (1951) Beitrag zur Kenntnıs der Pollenfermente Planta (Berl) 39: 431-459

HEINEN, W (1963) Allgemeıne Charakterisierung eınes Enzyms, in H F LiNSKENS \& $\mathrm{M}$ V TRACEY, Madern Methods of Plant Analysis 6: 310-322 Sprınger, Berlın-Gottıngen-Heldelberg

HELLERMANN, L , K A SCHELLENBERG \& o K REISS (1958) L-glutamic acid dehydrogenase II Role of enzyme sulfhydryl groups $J$ Biol Chem 233: 1468-1478

HOLZER, H \& G HIERHOLZER (1963) Hemmung der Synthese von DPN abha ngiger Glutamatedehydrogenase in Hefe durch Actınomycın C Biochim Bıophys Acta (Amsterdam) 77: 329-33I

HSIANG, T H (195I) Physıological and biochemical changes accompanyıng pollınation in orchid flowers I General observations and water relations Plant Physiol 26: 441-455

IWANAMI, Y (1956) Physiological researches of pollen $X$ The absorption of sugars and some enzyme reactions Bot Mag (Tokyo) 69:91, 198-205

JOHRI, B M \& I K VASIL (1961) Physiology of pollen Bot Rev 27:325-381

KONAR, R N \& H F LIVSKENS (1966a) The morphology and anatomy of the stigma of Petunia hybrida Planto (Berl) 71 : 356-371.

- \& (1966b) Physiology and biochemistry of the stigmatic fluid of Petunia hybrida Planta (Berl) 71:372-387

KORITZ, S B \& P P COHEN (1954) Colorimetric determınation of carbamylamıno acids and related compounds $J$ Biol Chem 209: $145-150$

LARSON, D A (1965) Fine-structural changes in the cytoplasm of germinating pollen Amer J Bot 52: 139-154

LINSKENS, H F (1955) Physıologische Untersuchungen der Pollenschlauch-Hemmung selbststerıler Petunien $Z$ Bot 43:1-44

(1958) Zur Frage der Entstehung der Abwehr-Korper bel der Inkompatıbilitat Reaktion von Petunia I Mitteılung Versuche zur Markıerung der Griffel mit P $^{32}$ und $\mathrm{C}^{14 .}$.Verbindungen Ber disch bot Ges 71:3-10 
(1959) Zur Frage der Entstehung der Abwehr-Korper bel der InkompatıbilitatsReaktıon von Petınıa II Mitteilung Versuche mit radioaktıv markiertem Pollen Ber disch bot Ges 72:84 92

(1964a) Pollen physiology Ann Rev Plant Physiol 15.255-270

(1964b) Biochemistry of incompatıbility, in Genetics today Proc XIth Internat Congr Genetics The Hague, 3: 629-636 Pergamon Press, Oxford-London-EdinburghNew York-Parss-Frankfurt

- \& K FSSCR (1957) Uber eine spezıfische Anfarbung der Pollenschlauche Im Griffel und die Zahl der Kallosepfropfen nach Selbstung und Fremdung Naturwissenschaften 44: 16

- \& - (1959) Stoffaufnahme der Pollenschlauche aus dem Leitgewebe des Griffels Proc Kon Nederl Akad Wet (Amsterdam) C 62: 150-154

- \& J TUPY (1966) The amino acid pool in the style of self-incompatible strains of Petunia after self- and cross-pollınation Zuchter 36: $15 \mathrm{I}-158$

LUND, H A (1956) Growth hormones in the styles and ovaries of tobacco responsible for fruit development Amer $J$ Bot 43:557-568

MAKINEN, Y \& J L BRTWBAKER (1967) Isoenzymes polymorphism in fowerıng plants III Diffusion of enzymes out of intact pollen grains Physiol Plant In press

mascarenhas, J P (1965) Pollen tube growth and RNA synthesis by tube and generative nuclet of Tradescantia Amer $J$ Bot 52.617

NICHOL, L W, J L BETHUNE, G KEGELES \& E L HFss (1964) Interactıng proteın systems, in h NFURATh, The Protems 2: 305-403 Acad Press New York-London

OCHOA, $s$ (1955) Crystallıne condensing enzyme from pig heart, in $S$ P colowick \& $N$ o KAPLAN Methods of Enzymology 1:685 689 Acad Press New York

ORNSTEIN, L (1964) Disc Electrophoresis I Background and theory Ann NY Acad Sct 121: 321349

OSTAPENKO, V J (1960) Physiological and biochemical characteristics of pollen and pistillate tissues of certain members of the Rosaceac Plant Physiol 7:444-449

PATON, J a (1921) Pollen and pollen enzymes Amer $J$ Bot 8:471-501

PLUYM J VAN DER and h F LINSkens (1966) Feinstruktur der Pollenschlauche im Griffel von Petunia Zuchter 36: 220-224

podduhnaya-ARnOLDi, V A, N V Zivger, T P pFtrovskaja \& v N polunina (1961) Histochemical study of the pollen grains and pollen tubes in Angıosperms $\operatorname{Rec} A d v$ Bot 1: 682-685

POLYAKov, I y (1964) New data on use of radioactive isotopes in studying fertilization in plants, In H F LINSKens (ed ), Pollen Physıology and Fertiltzatıon, 194-199 North-Holland Publ Comp Amsterdam

PYL'NFV, V M (1962) Fffect of pollination on the histochemical nature of wheat pistils Dokl Mosk Sel'skokhoz Akad I K A Timiryaseva 77:95-104

- \& P N PYL'NEVA (1963) The carbohydrate-proten metabolism in the pistil of crosspollınated wheat Dokl Mosk Sel'skokhoz Akad 88:25l-256

ROBLRTS,D B (1966) Immunochemical and enzymatic studies on glutamate dehydrogenase and a related mutant protein from Neurospora crassa $J$ Bact 91 : 1888-1895

ROSEV, W G, S R GAWLIK, W V DASheK \& K A SIEGERSMUND (1964) Fine structure and cytochemistry of Lilium pollen tubes Amer $J$ Bot 51:61-71

SANWAL, B D (1961) Diphosphopyridine nucleotide and triphosphopyridine nucleotide lınked glutanic dehydrogenases of Fusarıum Arch Blochem Bıophys 93: 377-386

SASSEN M Y A (1964) Fine structure of Petunia pollen grain and pollen tube Acta Bot Neerl 13: 175-181

SCHLOSSER, K (1961) Cytologische und cytochemische Untersuchungen uber das Pollenschlauch-Wachstum selbststeriler Petunien $Z$ Bot 49: 266-288

SCHOCH-BODMCR, H \& P HUBER (1945) Auflosung und Aufnahme von Leitgewebe-Substanz durch dic Pollenschlduche Verh Schwetz Naturforsch Ges (Zurıch) 125: 161-162

\& (1947) Ernahrung der Pollenschlauche durch das Leitgewebe Viertelj Schr Naturforsch Ges (Zurich) 92: 43-48 


\section{ENZYME ACTIVITIES DURING PROGAME PHASE IN PETUNIA}

SIMON, E. J. \& D. SHEMIN (1953): The preparation of S-Succinyl coenzyme-A J. Amer Chem. Soc. $75: 2520$

STANLEY, R. G. (1958): Methods and concepts applied to a study of flowering in pine. The

Physiology of Forest Trees. Symposium Harvard Forest 1957. 583-599. Ronald Press: New York.

(1964): Physiology of pollen and pistil Scr. Progr 52: 122-132

\& H. F LINSKEvS (1964) Enzyme activation in germınatıng Petunia pollen. Narure (Lond) 203: $542-544$.

$\&-(1965) \cdot$ Protein diffusion from germinating pollen. Physiol. Plant 18: 47-53.

\& L. c. T. YouNG (1962) Deoxyribonucleic acid synthesis or turn-over in non-dividing pollen cells of Pine Nature (Lond) 196: 1228-1230.

STRAUB, J (1946): Zur Entwicklungsphysıologie der Selbststerilitat. Z. naturforsch. 1: 287-291. TAKATS, $\mathbf{S}$ T. (1965). Non-random nuclear orientation during DNA synthesis in Tradescantıa pollen grains $J$ Cell Bıol 25: 151-157.

tano, s. and H. TAKaHaShi (1964). Nucleınsaure-Synthese im wachsenden Pollenschlauchen. $J$ Blochem (Tokyo) 56: 578-580.

TUPÝ, J (1961a): Changes in glucose and fructose level in Nicotiana alata styles and ovaries accompanying compatıble pollen tube growth. Biol Plant. (Praha) 3: 1-14.

(196/b) - Investıgation on free amıno acids in cross-, self- and non-pollınated pistıls of Nicotiana alata Biol. Plant. (Praha). 3: 47-64.

Vinson, C. G. (1927) Some nitrogenous constituents of corn pollen. J. Agr. Res. 35: 261-278.

ZiNGer, v. v. \& T. P. PLtrovskaja-baranova (1961): The coat of a pollen grain as a living, physiologically actıve structure Dokl. Akad Nauk SSSR 138: 466-469.

zONDAG, H. A. (1964) B Bepaling en diagnosische hetekems van de melkzuur dehydrogenase isoenzymen. Thesis, Groningen. 



\section{STELLINGEN}

I

Tijdens de groei van de pollenbuizen door de stijl van Petunia heeft interactie plaats die o.a. resulteert in veranderıngen van specifieke enzymactiviteiten. Deze interactie is niet bcperkt tot de plaats waar de pollenbuizen in contact zijn met het stijlweefsel

$$
\text { Dit proefschrift. }
$$

II

Het glutaminezuurdehydrogenase $(\mathrm{GDH})$ van $\mathrm{S}_{3}$ pollen heeft andere eigenschappen dan het $G D H$ van de $S_{1} S_{2}$ plant.

Dit proefschrift.

\section{III}

De activiteitsverhoging van het GDH (amin.) in de stijl van Petunia na bestuiving kan toegeschreven worden aan een den-ovo synthese van het GDH van de pollenbuizen. Het GDH (desamin.) van de stijl wordt geactiveerd.

Dit proefschrift.

\section{IV}

Het voorkomen van ringvormige DNA structuren zowel in bacteriën als in mitochondriën is een argument voor de hypothese, dat bacteriën gedurende de evolutie als onmisbare symbionten in organismen zijn geîntegreerd.

R. I. Baldwin in: I. C. Glinsalus \& R. Y. Stavifr: The Bacteria V, 340-342, 1964. A. M. KroON, P. Borst, E. F. J. van Brugrgin, G. J. C. M. Ruttenglrg: Proc. Nat. Acad. Sci., 56, 1836-1843, 1966.

V

Transplantatie van isogene celkernen in ontkernde eicellen van amphibieën is een veelbelovende methode om genetisch identieke individuen te verkrijgen; men dient echter wel rekening te houden met het in het cytoplasma aanwezige hereditaire materiaal.

F. P. Voi Pe en R. G. Mc Kinnlle: J. Herfdity, 57, 167-174, 1966. 
Bu het gebruık van de polygrdaf als leugendetecter moet men zeer voorzıchtıg 7ijn bij de beoordelıng van het veinzen, daar het instrument reacties van fisiologische mechanısmen registreert, die door mensen geinterpreteerd worden.

B M Smiril Scientıfic Amer 216, 25-31, 1967

\section{VII}

De Lemnaceae 7ijn phylogenetısch df te leıden van het genus Pıstıa (Araceae) door het aannemen van paedogenese.

A L Takmtajan in $P$ H Davis en $V$ H Herwood Principles of Angiosperm Taxonomy, 158, 1965

\section{VIII}

De snelle toeneming van het aantal klassen in de syntaxonomie is niet inhaerent aan de ontwıkkcling van deze wetenschap en dus een ongewenst inflatieverschujnsel.

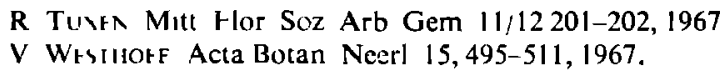

R Tuyks Mitt Flor Soz Arb Gem 11/12 201-202, 1967

$V$ Wrstrotf Acta Botan Neerl 15,495-511, 1967.

IX

Voor cen succesvolle plantenveredeling is het noodzakelıjk een inzıcht te krıjgen in de stoffelıke basıs van natuurlıjke incompdtıbıliteıtsbarrıères.

$\mathrm{X}$

Replıcerend DNA van zoogdıercellen ondergaat specıfieke en ırreversıbele veranderıngen bij de extractıe volgens standdardmethoden.

\section{$\mathrm{XI}$}

Een van de genıaalste uitvındıngen van de evolutie is, dat riten van kalmerıng en begroetıng zijn ontstaan uit omgerichte agressicbewegingen.

K LOREvZ Overagressic buj dier en mens 1966

\section{XII}

De mens zockt compensatıe om de afwıkıng van de norm te corrıgeren. 

